University of Nebraska - Lincoln

DigitalCommons@University of Nebraska - Lincoln

\title{
A RIDDLE AND A SONG: PLAYING WITH SIGNS IN A FOURTEENTH-CENTURY BALLADE
}

Peter M. Lefferts

University of Nebraska-Lincoln, plefferts1@unl.edu

Follow this and additional works at: https://digitalcommons.unl.edu/musicfacpub

Part of the Music Commons

Lefferts, Peter M., "A RIDDLE AND A SONG: PLAYING WITH SIGNS IN A FOURTEENTH-CENTURY BALLADE" (2007). Faculty Publications: School of Music. 28.

https://digitalcommons.unl.edu/musicfacpub/28

This Article is brought to you for free and open access by the Music, School of at DigitalCommons@University of Nebraska - Lincoln. It has been accepted for inclusion in Faculty Publications: School of Music by an authorized administrator of DigitalCommons@University of Nebraska - Lincoln. 


\section{A RIDDLE AND A SONG: PLAYING WITH SIGNS IN A FOURTEENTH-GENTURY BALLADE}

In a rich and learned article, Lawrence Gushee explored the tabula monochordi of Magister Nicolaus de Luduno. ${ }^{1}$ The tabula, which was copied into a music theory manuscript of $c .1400$ of southern Italian provenance (Rome/St. Paul), ${ }^{2}$ consists of three associated parts. The first and third I shall call, following Gushee, the tabula figurarum (an elaborate musical example) and the tabula numerorum (an extremely elaborate table of corresponding information). Between them lies the enigmatic text of a six-stanza musical puzzle poem, ' $\mathrm{Ut}$ pateat evidenter', with which Gushee wrestled inconclusively. ${ }^{3} \mathrm{~A}$ concordance to the poem unknown to Gushee in an English music theory manuscript of about the same age (Bodley 842$)^{4}$ associates

L. Gushee, 'The Tabula Monochordi of Magister Nicolaus de Luduno', in G. M. Boone (ed.), Essays on Medieval Music in Honor of David G. Hughes (Isham Library Papers, 4; Cambridge, Mass., 1995), pp. 117-52. My indebtedness to this resourceful essay will be everywhere apparent below. I would also like to take the opportunity to thank a number of individuals who generously commented on earlier versions of this essay or have provided me with valuable information, including Neil Adkin, Margaret Bent, Bonnie Blackburn, Bert Hall, Harry Ide, Raymond Haggh, Leofranc Holford-Strevens, Thomas J. Mathiesen, Stefano Mengozzi, George Rigg, Anne Stone and Roger Wibberley.

Summarising Gushee (pp. 117-28), whose inventory and account of the Rome/St. Paul source are now the best available, the original manuscript, perhaps from Angevin Naples, dates to c. I400 plus or minus thirty years. In the eighteenth century it was in the Barberini collection, where it was dismembered so that one fascicle of eight folios (fols. 17-24) could be sent to Padre Martini, who in turn gave it to Martin Gerbert, who brought it to St. Blasien. Along with some other manuscripts from St. Blasien, this fascicle now resides in Sankt Paul im Lavanthal in Kämten, Stiftsbibliothek (Archiv des Benedictinerstiftes), where it is MS 135.1. The manuscript from which this fascicle was taken is now Vatican City, Biblioteca Apostolica Vaticana, Barb. lat. 307. The tabula monochordi is found in the St. Paul fascicle, fols. 18 -22 .

Gushee considers the text on pp. 140-2. The tabula figurarum and poem are written out across the top half of the two-page opening of fols. $18^{\mathrm{v}}-19$. After Ut pateat ezidenter but before the table of data there is an explicit (EXPLICIT TABULA MONOCHORDI MAGISTRI NICOLAI
DE LUDUNO DEO GRATIAS ANIEN). Thus on the face of it the tabula monochordi is simply the musical example and the poem is to be associated with it rather than with the following material. Nevertheless, I agree with Gushee that the tabula figurarum and tabula numerorum belong together, as will be made clear below.

Oxford, Bodleian Library, MS Bodley 842 , fols. $45^{*}-46$. According to John Snyder, Malcolm Parkes has dated the main hand of this manuscript to the very latest fourteenth or earliest 
these cryptic verses with a polyphonic chanson, a two-voice ballade that has never been published. ${ }^{5}$ The ballade is a sophisticated demonstration piece for tonal and mensural behaviours, and I believe that this song is the original complement and key to the poem's meaning. It also offers a significant new point of entry into the complicated world of Anglo-French tonal theory as it developed in treatises and compositions of the fourteenth century.

The English source of Ut pateat evidenter is reproduced as Figure 1. Across a two-page opening, cantus and tenor are written out in separate parts, with the text carefully underlaid to the cantus line as if for singing. When the text is copied out according to its versification, it reveals itself to be a double ballade of six stanzas unified by a refrain and sharing rhyme scheme and syllable count. Versification is conventional for fourteenth-century ballades, namely, seven lines of eight syllables each, rhyming ababbc. ${ }^{6}$

fifteenth century, with a preference for the later side of this time range See Snyder 'A Road not Taken: Theinred of Dover's Theory of Species', Jountime range See Sus ter, 'A Road (1990), pp. main hand in 'The B $14, n$. 18. 'This date concurs with Gilbert Reaney's assessment of the (1957), pp. 31-7, at priarum Regulare Musice of MS Oxford, Bodley 842', Musica Disciplina, I] fiftenth century is an error; in fact, it sertion (p. 31-2) that Ut pateat is a later addition of the of the manuscript, Christian in fact, it is copied by the main hand. In the most recent inventor of the fourteenth century. Meyer dated the hand very differently, ascribing it to the first hal in Great Britain and in the See The Theory of Music: Manuscripts from the Carolingian Era up to c.1500 (RISM B/III/4; M the Unted States of America, ed. C. Meyer, M. Huglo and N. C. Phillip A manuscript whose recorded pp. 110-15, at p. 110.

copied in the main hand of Bodentents are identical in title and order to four of the treatises the Augustinian Friars of Bodley 842 was entered in a medieval catalogue of the library of Augustinian Friars ariars at York. See M. R. James, "The Catal catalogue of the library of Augustinian Friars at York, now first edited fromes, The Catalogue of the Library of the in Fasciculus Ioanni Itillis Clork Dicatus (Camber the Manuscript of Trinity College, Dublin' among the additions made 'not Dicatus (Cambridge, 1909), pp. 2-96, at p. 83, no. 645. It falls as the donation of Magister Juch later than the original' (p. 5), i.e., not long after 1372, 1372. Reaney believes Bodley $8+2$ ghome, who was one of the brothers of the convent in pp. 32-3). James belis Bo copy of this York codex (Reaney. 'The Brevinum', extant remains of the Yodey 842 to be the original and the (Reaney, 'The Bro possibility, which is York library ("The Catalogue', $p$, 9 ). Nolains it as one of the few offers a which is supported by Meyer's minogue', p. 96). Nothing rules out the latter

5 I was first alere terminal date for Lt pateat not the main hand. Thi unpubst alerted to the existence of this cot long after 1372 .

unpublished conference paper. My atention wasion in 1980 by Dr Roger Wibberley in an its text into the Thesaurus. Ifusicarum Lattention was redrawn to it when I undertook to enter

- Tr Gushee's article, a coincidence whinam database, shortly after which time I discovered There are, for instance, five seven-line has led to the present study.

ababbc C (nos. 2, 13, 24,30,37 in -line Machaut ballades with octosyllabic lines rhyming of the remainder de. Sachaut: 4 Guide Rectosyllabic lines rhyming aballade no. 38 is the most similar lines are used Research (New York, 1995), pping ababbcbC). See L. Earp, Guillaume point.

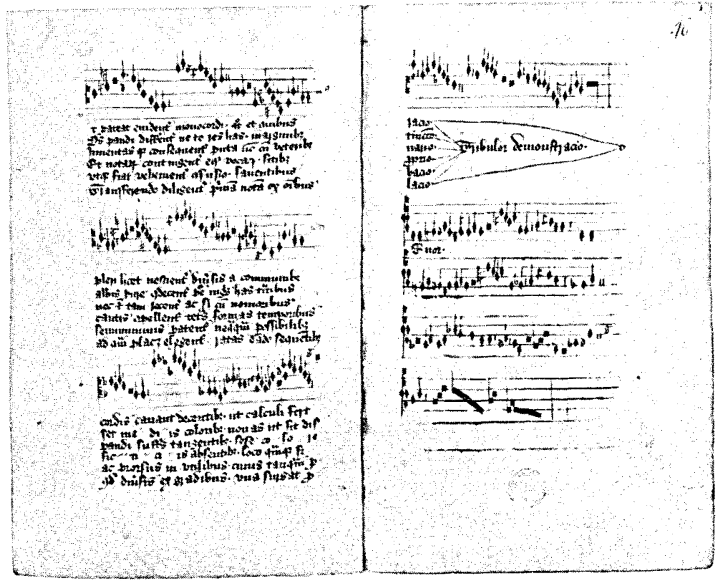

Figure 1 Ballade Ut pateat evidenter. Oxford, Bodleian Library, MS Bodley 842, fols. $45^{\mathrm{v}}-46$. By permission of the Bodleian Library

Both surviving versions of the text are flawed but, luckily, most imperfections in the Bodley 842 reading can be improved by reference to the Rome/St. Paul text and vice versa, and my edition proposes a few further emendations. For the text and a translation, see Appendix 1.

To understand how this is a double ballade, the music must first be transcribed (see Appendix 2), which is not a difficult task and reveals two crucial features. As is already apparent by a glance at the original notation, there is a proliferation of chromatic inflections. Less obvious to the eye at first, but falling out under the transcriber's pen due to the motivic, contrapuntal and mensural behaviour of cantus and tenor, is the fact that the composition, without the benefit of mensuration prolations from $9 / 8$ to $6 / 8,3 / 4$ and $2 / 4$ under minim equivalency. ${ }^{7} \mathrm{~A}$ quick scan of the text is enough to realise that whatever its

\footnotetext{
This was first brought to my attention by Roger Wibberley. See above, n. 5 .
} 


\section{Peter M. Lefferts}

detailed meaning, which will be pursued below, it is concerned with these very features: the first three stanzas discuss tonal behaviour while the second three discuss mensural behaviour. Ballades are normally three-stanza poems. Hence these twice-three stanzas form a double ballade, unconventional simply in that all text is to be sung to one melodic line, rather than assigning the two texts to be unfolded simultaneously in cantus and triplum parts. ${ }^{8}$

The layout of music and text have been carefully coordinated in Bodley 842. Two statements of the prima pars of the ballade (I.1, I.2) each occupy their own line of score, with accompanying text couplets beneath. The secunda pars is divided into three segments (II, III, IV). The third cantus staff holds the first two of these (II, III), underlaid by two text lines, and the fourth staff holds the final one (IV), which corresponds to the textual refrain. These larger periods are readily identifiable by cogent melodic and cadential gestures terminating in semibreve rests, and they are subdivided into shorter musical phrases ending in minim rests. The textless tenor is inscribed in four staves paralleling the layout of the cantus. The lyrics surely could have been sung to this music; underlaying them declamation transcription it is not hard, and the resulting style of declamation, with one or two syllables per breve, is not atypical for the rhythmic--mot ballade. Our song's musical language, judging by sations, rhyme betions, be termed middle-period Machaut. ${ }^{9}$ Lack of musical the lack of tonal coincidence and the final (refrain) cadence, and and the final coincidence in the cantus between the clos cadence middle years sonority $(b b$ versus $c),{ }^{10}$ both speak for a date in the (he century, although$$
\text { (n) }
$$

Schrade of polyphonic double ballades include Paris and The It'ris's of Guillaume de Machaut (Polyphaut, Quant Theseus/Ne quier reoir, ed. L. Perular Mond Monaco, 1956), no. 34; Grimace, (Polyphonic Music of the Fourteenth Century, 3; Secular. Music (Polyphonic Music of the Foure, Se Zephinus/Se Jupiler, ed. G. K. Greene, in Frenth 15; and F. Andrieu, Ames amours /O Fourteenth Century, 18; Paris and Monaco, 1981), no. (Polyphonic Music of the Fourteenth Cent flours, ed. G. K. Greene, in French Secular Music comprehensive bibliography on Century, 19; Paris and Monaco, 1982), no. 84. For a 9. Nachaut, pp. 362-4,373-4 on the Machaut and Andrieu ballades, see Earp, Guillaume de Among the Machaut bal, 386-7.

Experance qui m'asseure, is most com corresponding line and syllable count (see n. 6), no. 13, in other style features.
Note namest comparable in the rate of declamation; it also bears comparison Pitch-class will not follon

octave as subes are capitalised. Regholtz code, but rather will be distinguished as follows. octase as subgrave $F F$ GG (Gamma-ui), gally localised notes are italicised and identified by ve $A-G$, acute $a-g$, superacute $a a-g$
A Riddle and a Song

it may be that the musical goals about to be investigated militated against a more conventional shape.

Unfortunately, the vagaries of transmission have provided us with an inconsistent musical text whose tonal ambiguities are not as immediately resolvable as its rhythmic-metric defects. The principal problem is in the prima pars, where one needs to decide whether I.I and I.2 were intended as identical, or whether they have contrasting endings, differentiating ouvert and clos. Following the principle of lectio difficilior potior, my transcription reads intentionality into the conflicting manuscript accidentals in cantus and tenor over the last two breves of the section, interpreting them as defining first and second endings of varied tonal content.

\section{TONAL BEHAVIOUR AND NOTATION}

We clearly have on our hands what Thomas Brothers has called a 'musica ficta essay'. ${ }^{11}$ Notated accidentals in our ballade include four sharps (on F, C, G, D) and six flats (on B, E, A, D, G, C) for a total of seventeen notes around the cycle of fifths from $D \#$ to $C$ b . Because the tenor never descends below grave $C$, we do not know whether the composer thought in terms of a pitch collection with graveregister $B \nmid$ or $B b$, a point whose relevance will become clearer below. The song begins in a bright realm of sharps and moves towards a dark realm of flats at the end of the prima pars, plunging in the secunda pars to its flattest point in section II before shedding flats in section III (though not without a brief feint to $\mathrm{D} b$ ) and emerging into the light of white-note diatonicism in section IV. Moreover, section II is clearly a varied and compressed restatement of section I in which the same musical figures have been inflected with flats instead of sharps. This relationship is highlighted by the initial patterning of accidentals: in section I, they are acute $d \sharp$ and $f \sharp$, lying a third apart and rising; in section II they are acute $d b$ and $b b$, again a third apart but falling. ${ }^{12}$ As an additional novelty, while

${ }^{11}$ T. Brothers, Chromatic Beauty in the Late Mediezal Chanson: An Interpretation of Manuscript Acridentals 12 Cambridge, 1997), pp. 138-42.

It would be more conventional to find them a fourth apart (D\# and $\mathrm{G} \#$ reflected by $\mathrm{D}$ b and $\mathrm{Ab}$. This would provide the missing cantus $\mathrm{G} \#$ and $\mathrm{Ab}$, and there is a certain elegance not inappropriate to our piece in the juxtaposition of $\mathrm{C} \# / \mathrm{D} b$ and $\mathrm{G} \# / \mathrm{Ab}$. However, $F \#$ then would not be signed in the cantus in section I, nor Bb in section II. Note that the F is later cancelled. (Perhaps $\mathrm{F}_{4}$ was intended as part of a chromatic $\mathrm{C}, \mathrm{D}, \mathrm{E}, \mathrm{F}$ tetrachord.) If the 
the means of notating non-diatonic notes of the gamut is by the use of the familiar signs for sharpening and flattening, the method of cancellation of these signs is unusual: the letter name of the note is written in the appropriate line or space at a later point. Both the extreme accidentals and their method of cancellation help to provide a context for our ballade.

\section{Extreme accidentals}

Concerning the accidentals, it must first be said that $\mathrm{C} b$ has no counterpart in compositions of the fourteenth and early fifteenth centuries, which otherwise do not venture beyond the sixteen notes better the cycle of fifths between $\mathrm{D \#}$ and G $b .{ }^{13}$ Furthermore, while better known, systematic musica ficta essays of the later fourteenth Aon pursue the the chansons Fumeux fume, Calextone qui fu and Le mont with characteristiclications of hexachordal thinking, driving ficto cycle-of-fifth flatteningential figures, parallel thirds and sixths, and

For compartening, these are not the methods of our ballade..$^{14}$ and even hare radicality, then, one must look into music theory, evidence for us to pickings are slim. Nevertheless, there is enough concerns, and to be able to distinguish two different theoretical diatonic gamut two different angles, that yield additions to the that will help to situaching those as dramatic as in the ballade and rigorous, systematic in time and place. One involves the incorporate more expansion of the gamut specifically in order to through the fourteenth methodically. From the twelfth up ated with a small numbentury, this approach is particularly associwho develop ways of northern French and English theorists develop ways of generating pitches with tetrachords and

understanding of the

with $\mathrm{D \#}$ and $\mathrm{G} \#$, and $\mathrm{B}$ b in a hexachordally, as will be explainedstem with $\mathrm{A}_{6}$ and $\mathrm{D} b$, but these signs do not operate 13 unexplicable.

signs for $\mathrm{A}$, and $\mathrm{G}^{\sharp}$ therefore remain

Chanson', Plainsong and Medienal Systems and Tonal Types in the Fourteenth-Century French sixcen tones may be some Kindusic, 4 (1995), pp. $117-47$, at pp. 122 . For the not Gioseffo Zarlino (Cambrideones of Accidental Inflections limit rooted in hexachordal practice, see See P. M. I (Cambridge, 1987), p. 30 . pp. 176-83, and "Sibrilas in

(19), Chromatic Beauty, for exage of Fumeux fume', Early Music, 16 (1988). hexachords, especially in synemmenon and coniuncta theory. ${ }^{15} \mathrm{~A}$ seventeen-note system one step sharpwards from our ballade, thus with five flats through $\mathrm{G} b$ and five sharps through $\mathrm{A} \#$, is already known from an English treatise, Sequitur de synemenis, of the mid- to later thirteenth century, for instance. ${ }^{16}$ With an eye to the famous modern justifications causa necessitatis and causa pulcritudinis of musica falsa, we might call this approach the causa generationis, since tones beyond those of the diatonic gamut are being explicitly generated and accounted for.

The other theoretical concern can be called neo-Boethian. It involves how to describe all possible intervals according to their semitonal content and by means of proportional arithmetic, and how and where to locate them on the staff system. This approach is epitomised in the massive Second Book of the Speculum musice of Jacques de Liège from the mid-1320s. ${ }^{17}$ Jacques proposes a total of fifty-one intervals, counting the unison, three intervals that he cannot represent on the gamut (the comma, the lesser tone of two minor semitones, and the greater tone of two major semitones), forty-four intervals that can be written in the gamut between Gamma-ut and $e e$, thirty-seven of which are diatonic and seven that can only be written using musica falsa, and three additional large intervals rising above the standard gamut from Gamma-ut to ff, gg and

${ }^{15}$ There is a convenient summary in Brothers, Chromatic Beauty, pp. 33-9, to which one certainly could add two items from pertinent sources, Theinred of Dover, De legitimis ordinibus pentachordorum et tetrachordorum (Bodley 842, fols. $\left(-44^{7}\right.$ ), edited by John Snyder (Ottawa, 2006), pentachordorum et tetrachordorum (Bodley 842 , fols. $1-44^{\prime}$ ), edited by John Snyder (Ottawa, 2006), 17). The Bodley 842 context for Ut pateat ecidenter associates the ballade with the preceding treatise of Theinred, whose greatest novelty is a highly original theoretical justification of chromatically altered notes in plainchant $\left(\mathrm{E} b, \mathrm{~F}^{\sharp}, \mathrm{CH}\right)$ via tetrachordal constructs. In the Rome/St. Paul fascicle, the tabula monochordi, including Ut pateat eridenter, immediately follows two other elaborate the rota is tonally presorat ste three, thus prove progrive, adding two hexachords, on B providing hexachordally for $\mathrm{E} b$ and $\mathrm{F} \#$. Its pitch collection includes seventeen discrete notes per octave (accounting for all of the twelve minor semitones and five commas), defined as the white-note diatonic set of seven plus five sharps (to $A$ ) and five flats (to $G b$ ); an anomalous nomenclature for raising $A$ that Gushee has pointed out might indicate some sensitivity ${ }_{16}$ involving this note (see Gushee, pp. 130-3, 136-7).

The anonymous Sequitur de snnemenis has been newly edited in Prosdocimo de' Beldomandi, Brief Treatise on Ratios that Pertain to Music and A Little Treatise on the Method of Dividing the Monochord, ed. and trans. J. The rota componsitionis mono monochord (see the note above) is an array of pitches whose means of generation is unspecificd, but in which the intention is nonetheless to display a particular collection; it has an obvious affinity with Sequitur de synemenis in its $5+5$ disposition of flats and sharps.

Jacobi Leodiensis Speculum musicae, 7 vols., ed. R. Bragard (Corpus Scriptorum de Musica, 3; [Rome], 1955-73), ii. 
$a a .{ }^{18}$ These amount to twenty distinct intervals plus octave transpositions. (See Table 1, where where $\mathrm{m}$ is minor semitone, $\mathrm{M}$ is major semitone, the whole tone is $\mathrm{M}+\mathrm{m}$, and so forth.)

In his staff-notation examples, Jacques seldom strays from the white-note diatonic collection plus acute $b b$ and superacute $b b b$. However, by remarks such as 'si non fiat falsa musica', and 'exclusa falsa musica', he acknowledges that the intervals he systematically reviews can be written in other places than those where he demonstrates them but that these locations would require chromatic inflections. In some instances, however, he cannot avoid musica falsa. For example, where he chooses to notate them, the tetratonus of four consecutive whole tones requires grave $E_{b}$, the pentatonus of five whole tones requires grave $D b$ and $E b$, and the hexatonus of six whole tones requires a startling grave $F b$ along with $G b$ and $a b .{ }^{19}$ Jacques derives his hexatonus by the whole-tone descent from acute $e$ to grave $F$ b. (We could extrapolate the ballade's acute $c b$ by a similar descent of six whole tones from superacute $b b$, although Jacques never writes such a note.) As a neologism for this approach to the introduction of accidentals, which result as it were coincidentally or demonstration from the inadequacy of the diatonic gamut for the exemplificationis. and causa exemplificatio two new terms, causa generationis for pitches and distinctly two European Twean tonal theory.

Two further theoretical sources go beyond Jacques de Liège in
he intervallic justification of cationis and justification of extravagant accidentals causa exemplifiEngland or northern in some manner both to the ballade and to treatise of neo-Boeth France. The first of these is an unedited little 13 sheorval names,

Speculum musice, ed. Bragard, bk. 2,

recognises the arbitrariness of the esp. as summarised in cap. CXXVI (ii, pp. 300-7). Jacques possibility of notes both higher twenty-step gamut from Gamma-ut to when Gamma-ut is solmised $(f f, g g, a a a)$ and lower (implicitly $C C, D D, E F b, E E, F F, F F$ 19. pitches, grave-register $A b$ and $B b$ ). For these three intervals, see $S$ be. See ii, pp. 300-2.

XLVIIII; ii, pp. 217-19 and Speculum musice, ed. Bragard, bk. 2, ii, pp. 207-8 and App. intervals that cannot be written. LIIb; ii, pp. $224-8$ and $A$. 2, ii, pp. $207-8$ and $A$ pp. cum bis diapason, semitonium mitten without musica falsa are the App. LVb. The remaining four diapason. There are also internus cum diapente et bis diapason and semitonus cum bis diapason, tritonus write.

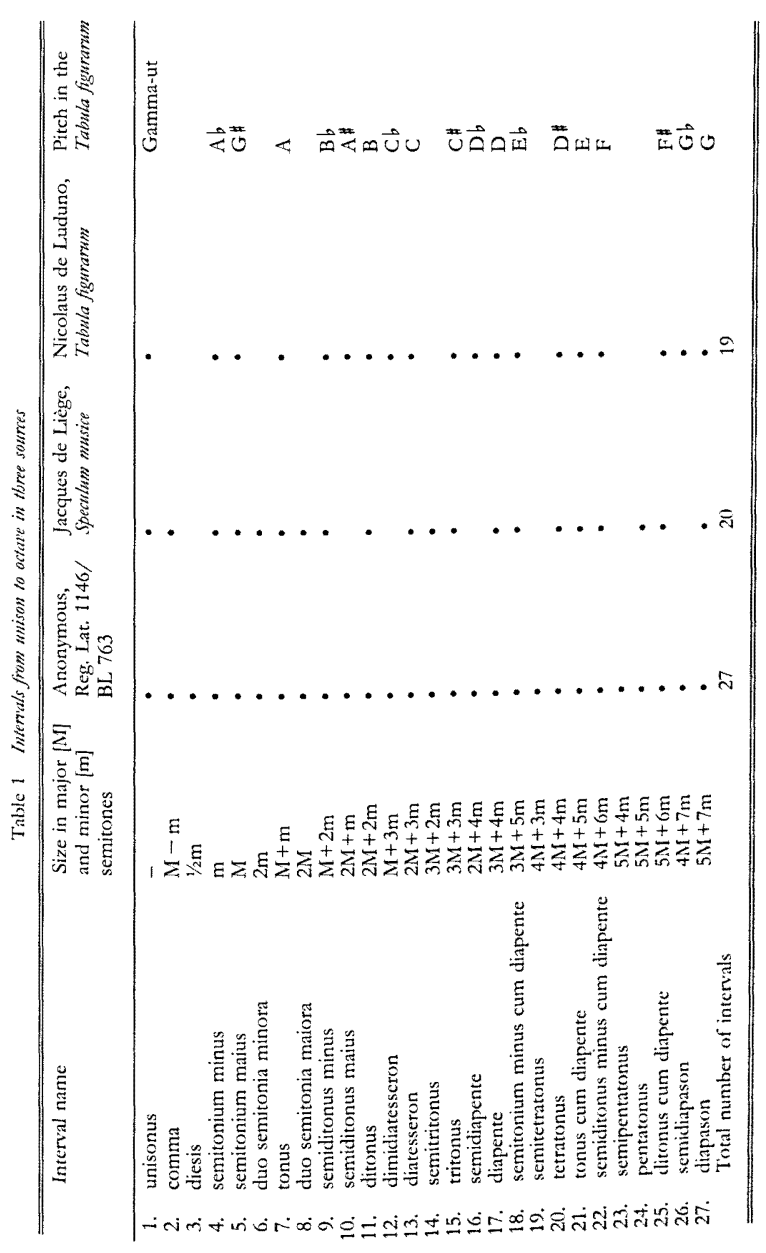

129 
their size as measured in tones and semitones, and their representation in the staff system. It survives in two English codices of the first half of the fifteenth century. ${ }^{20}$ (See Figure 2.) A general resemblance to the approach by Jacques de Liège in Book 2 of the Speculum musice is striking.

The total of thirty-five intervals represented in this English material includes the standard diatonic ones (semitonium minus, tonus, ditonus, dyatesseron, diapente, dyapason, etc.) along with more esoteric ones that require chromatic tones for their notation (comma, semitonium maius, semiditonus minus, semiditonus maius, demidiatesseron, semitritonus, demidiapente, etc.). Of these intervals, twenty-seven fall within an octave, and the remainder are reduceable to one of the twenty-seven plus an octave. (See Table l.) The logic of presentation is simple: incremental growth in size $(\mathrm{m}$ $\mathrm{M}, 2 \mathrm{~m}, \mathrm{M}+\mathrm{m}, 2 \mathrm{M}$, etc.), with occasional irregularities in order to keep two intervals of the same type adjacent. ${ }^{21}$ For each interval there are two examples, usually a step apart and mostly written in the $C$ to $c$ octave. For one if not both examples, chromatic alterations are usually necessary. For instance, the diatesseron $(2 \mathrm{M}+3 \mathrm{~m})$ is represented by two diatonic intervals, $C$ to $F$ and $D$ to $G$, while the semitritonus $(3 \mathrm{M}+2 \mathrm{~m})$ is notated as what we would now call an augmented third, $F$ to $a \#$ and $G b$ to $b$. The comma is exemplified by $G \sharp$ to $a b$ and $a \sharp$ to $b b .{ }^{22}$ The core pitch collection

${ }^{20}$ The more complete and accurate version of this material is in Vatican City, Biblioteca Apostolica Vaticana, Reg. Lat. 1146, fols. $58^{v}-62^{2}$, which has a total of thirty-four intervals, some lacking clefs or manifestly wrong. The $58^{2}-62^{2}$, which has a total of thirty-four intervals, 763, fols. 91 $1^{-}-93^{r}$, also has thirty-four intervals, adding In London, British Library, Lansdowne lacking another, and is less rationally ordered one to the Reg. Lat. 1146 collection but occasionally improves on a Reg. Lat. 1146 reeding over the last ten examples; although material follows directly upon, or is embected wing it has more faults overall. In both cases this by Johannes Torkesey, Declaratio trianbuli et sed within, a copy of a fourteenth-century treatse Cambridge, Trinity College, NIS that likewise follows directly upon a For example, semidiapente and a version of Torkesey's Declaratio.

tritonus (interval 15) actually lies diapente (intervals 16 and 17 ) are adjacent, although the

22. Both sources begin with unison, between them in terms of size.

as the interval dividing unison, comma, diesis (a term here used in its less common meaning The diesis, so defined the minor semitone into two equal halves) and the minor semitone confusion. In Reg. Lat. in fact unnotatable. It is not surprising, therefore, to find error and $G$ and $G \sharp$ to $a$, which are mino accompanying music example represents the diesis by $F$ to representing the which are minor semitones (not what the text says is being shown, but in fact representing the more common meaning of the what the text says is being shown, but in fact $F^{*}$ to $G$ b (a comma) intervals $E^{\#}$ to $F$ b (which is actually a minor sowne 763 the diesis is notated ones with change of alas, the examples simply appear to have been copied from the previous

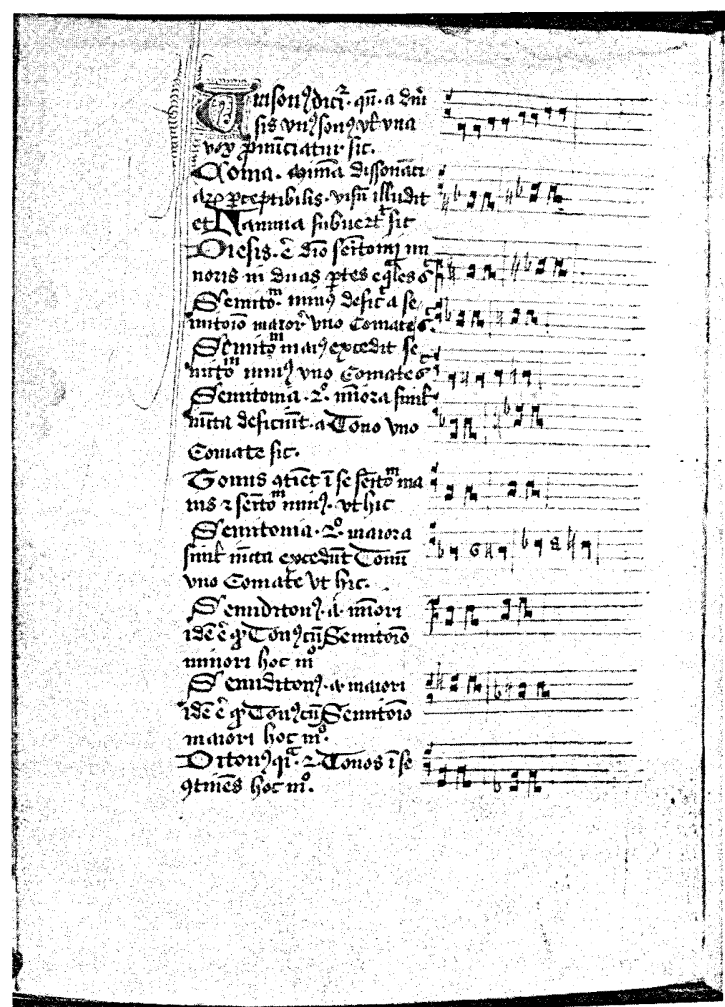

Figure 2 Anonymous treatise on intervals. London, British Library, Lansdowne 763 , fol. $91^{\circ}$. By permission of the British Library 


\section{Peter M. Lefferts}

that one can extract from this English material is again a seventeennote system, including five flats (through $G b$ ) and five sharps (through A\#), with grave-register $A b$ and $B b .{ }^{23}$ This English material is related to our Latin-texted ballade by its use of letter names for cancellation, a point to which I will return in a moment. ${ }^{2 f}$

For a confirmed sighting of the ballade's exotic $c b$, which occurs in a theoretical context of interval exemplification, I need to introduce one further treatise, the Musica (1357) of Johannes Boen, a Dutch priest who was educated around mid-century at Oxford and Paris. ${ }^{25}$ In its third part, a rigorous exploration of the potential of flat and sharp signs, Boen creates a number of extraordinary examples of intervals. He notates, for instance, a comma, two and three consecutive minor semitones, the interval comprising two and the and a minor semitone (the difference between $B \sharp$ and $C$ b) the differenal comprising a comma less than a minor semitone as far as the between $A \sharp$ and $C$ b). In all, his examples take him Astonishing seventh sharp (acute $b$ ). ('remorsus me, however, Boen then repents! Pricked by remorse possibilities stimulans'), he retreats from the more extreme cordi manualis') that haventional gamut ('extra naturam monodemonstrations that have come up in the course of his intervallic radical position ('quas supra gratia exempli solum posui') to a less understanding still in advance of the ancients in its use and terms we have of accidentals but more fully defensible. ${ }^{26}$ In the intervallic context coined, we see Boen explicitly reverting from an to a pitch context in which accidentals appear causa exemplificationis

23 The

overall range and content. Rerial, while sharing most examples in common, vary somewhat in twenty-step gamut from $G$. Reg. Lat. 1146, by rising only to $d d$, uses less than the standard adds three steps to the Gamma-ut to ee, though it has both grave $A$, and $B$, Lansdowne 763 has only grave $B$, as it lacks, the $F F$ below Gamma-ut and superacute $f f$ and $g g$ above ee, but Lansdowne example, without which the with grave $A b$. I am assuming a clef error in one octaves. The general similarity whe top note would be $c c c$, for a range a clef error in a half 2+ (c. 1375) is noteworthy (see Leffe to the tonal space described in the Berkeley theory treatise follows in Lenerationis yields another exotic pitch Systems', p. 122).

of the in Lansdowne 763 (fol. $93^{\circ}$ ), butic pitch in Lansdowne 763. In unrelated material that the apotome (major semitone) by the but in Reg. Lat. 1146, B \# is used in the representation 2. For biog a comma.

Borns. If usica und seine fonsonanzenlehre (Stun edition of the Alusica, see W. Frobenius, Johannes This paragraph draws upon Boen, (Stuttgart, 1971).
A Riddle and a Song

For the more limited but still exciting tonal possibilities to be put into writing, he argues, the necessary signs already exist to convert sounds into notation without inventing any further novelties, if the signs are used rationally at new locations in the gamut with the effects he has discussed. ${ }^{27}$

Boen's methodology for pitch generation may be described in the following way. (See Table 2.) Imagining the diatonic gamut to be mapped by overlapping diatonic tetrachords, Boen allows these tetrachords to be distorted on account of consonance or simply the playfulness of the melody ('propter consonantias vel lasciviam ipsius cantus'). ${ }^{28}$ Defining as soft the part of a tetrachord that ends in a semitone, and as hard the part that ends in a tone, he allows the soft part to be extended and the hard part to be contracted by a semitone, thus expanding or compressing the tetrachord and incurring non-diatonic pitches requiring accidentals. If a tetrachord has the semitone in the middle, so that there are tones at both ends, then either extension or contraction may occur at either end. Boen's principal constraint on this procedure is that tetrachords a fourth apart need to be able to be conjunct, that is, overlapping by one note such that the last note of the first tetrachord and the first note of the second tetrachord are the same. Thus, for example, the $E F$ $G a$ (mTT) tetrachord could be allowed $E$ or $E b$ and $a$ or $a b$. The $a b c d(\mathrm{TmT})$ tetrachord could be permitted $a \sharp$ or $a b$ and $d \sharp$ or $d b$. But since these two tetrachords must be conjunct, the $a$ \# possibility is ruled out. By this logic, fully extended across a gamut in which $B$ h is dictated in the grave register, a sixteen-note pitch collection results, consisting of the seven diatonic tones, four flats $(\mathrm{B}, \mathrm{E}, \mathrm{A}, \mathrm{D})$ and four sharps $(\mathrm{F}, \mathrm{C}, \mathrm{G}, \mathrm{D})$, plus $A \sharp$ in the grave register only. Boen recognises the registral diversity, noting that these things are not always the same at the fifth or at the octave ('Sic ergo non est semper simile in hac materia de clavibus dyatesseron constituentibus vel dyapason' [p. 64]).

${ }^{27}$ 'Ut hec lasciva iocunditas absque omnimoda novi monocordi compositione signari possit in scriptis, sicut habet fitas absque omnimoda novi monocordeat, rationabiliter eas litteras $e t$ earum effectus in diversis clavibus usus admisit.' Jbid. p. 63.

${ }^{29}$ The following in diversis clavibus usus admisit. Bid., p. 63. Frobenius, pp. 63-6. In this passage consononcia paragraphs draw upon Boen, Musica, ed. Frobenis, por the catsa necessitas and causa pulchritudinis of musica falsa. 
Peter M. Lefferts

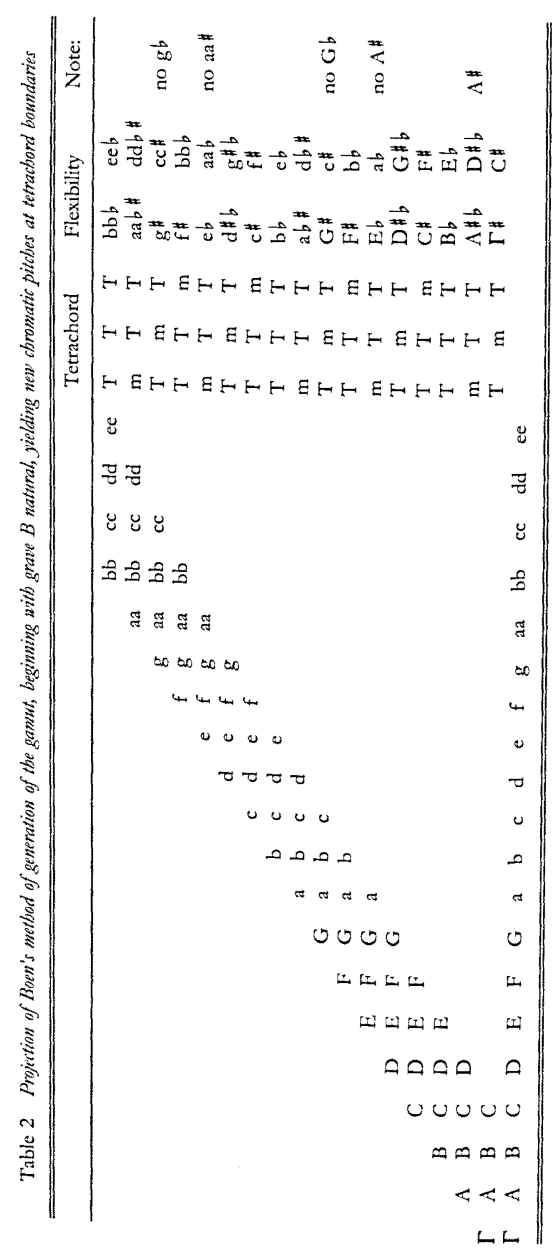

A Riddle and a Song

As just observed, this result is arrived at for a pitch collection with grave $B$ but not $B b$. Given the appearance of grave $B b$ in Nicolaus de Luduno's tabula, as well as, for instance, in the English interval examples and in the Berkeley treatise (1375), it is of some historical significance that Boen does not consider the alternative pitch collection triggered by admission of this pitch. However, given a close, critical reading of the passage at hand, it is far from certain that Boen intended his conclusion to be absolute and complete for the moderns. He says 'this is how I respond for the present' ('Respondeo pro presenti'), and he acknowledges the use of acute $a \#$ an octave above grave $A \sharp$, about which he can only say 'We know that a melody may be placed this way at other locations, which is allowable' ('scimus, quod huiusmodi cantus sub aliis clavibus, quibus hoc licitum est, ordinetur'; p. 64).

The result of applying Boen's register-sensitive tetrachordal logic to a gamut with grave $B b$ is, of course, to rotate his results a step flatward in the cycle of fifths. In the new sixteen-tone collection, $\mathrm{D} \#$ disappears while $\mathrm{G} b$ is added, and grave-register $A \sharp$ disappears while superacute $c c b$ emerges. (See Table 3). The sum of these two collections is a registrally inequivalent eighteen-note set with five sharps and six flats, i.e., from $A \sharp$ to $\mathrm{C} b$, in which $\mathrm{B} b$ occurs in all registers, $A \sharp$ occurs only in the grave register, and $\mathrm{C} b$ occurs only in the superacute register. We are very nearly at the pitch collection of the ballade.

Amplifying Boen is not merely an exercise in musicological flights of fancy. At the end of this extraordinary process we are within one note of the scale of the Tabula monochordi of Nicolaus de Luduno. The missing note that Nicolaus provides is acute $c b$, precisely the notated $c b$ of the ballade. (See Table 1, no. 12.) This note falls almost at the mid-point of his forty-eight-note gamut, which is at the $b-c$ half step mid-point of his forty-eight-note gamut, which is at the b-c hacked just above. Boen used this note causa exemplificationis but then back a away from justifying it causa generationis. Hence we may read a self-conscious significance into the most extreme notationsting that displayed in the ballade, and we may be justified in suspecting taidental. the association of poem and Tabula is anything but coincidental. Inescapably, it is time to look more closely at the tabula figurarum and the tabula numerorum of Nicolaus.

The tabula finter of twenty-four lines and tom istinct 
Peter M. Lefferts

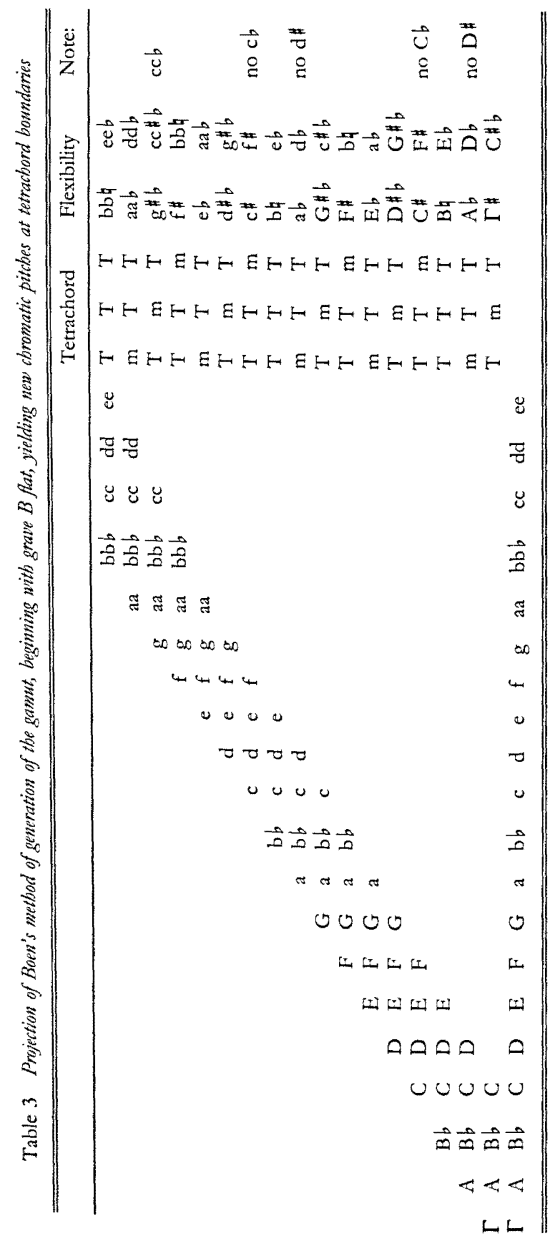

136
A Riddle and a Song

note in a gamut of forty-eight notes running two octaves and a sixth from Gamma-ut to ee..$^{29}$ As implied above, this gamut not only incorporates the standard seven diatonic notes (F, C, G, D, A, E, B) but also six flats $(B, E, A, D, G, C)$ and five sharps $(F, C, G, D, A)$, for a total of eighteen notes not enharmonically equivalent, with flats lying a comma below their neighbouring sharps. $\mathrm{B} b$ appears in the grave register as well as in the higher two registers, while $A \#$ appears only in the grave register and $\mathrm{C} b$ appears only in the acute and superacute registers.

In this diagram the standard gamut names are written up the left-hand side, and the additional sharps and flats are written up the right-hand side with an indication of the size of the smallest interval they specify, lyma (minor semitone) or comma (here, the difference between the minor and the major semitone). There are twelve lymas and five commas per octave. Across the giant staff system are written and rest groups in the symbols of French ars nova numerous notation and including mensural music, using red and no one has ever successfully demonstrated flagged semiminims. No one has ever successfully demond the fact that these note groups present a real piece of music, and spaces of the that they often move conjunctly across the lines and spaces of high staff, thus tracing melodic figures employing an exthat any kind degree of direct chromaticism,
of coherent piece is encoded.

The tabula numerorum, following the tabula figurarum and running The the Roul manuscript, is a compact yet unparalleled summa of data relating to nomenclamathematical representation of interval proportions. It contains six columns of complex technical informe forty-eight-note gamut, expressed as an mation on each pitch in the forty-exition of a interval above Gamma-ut. This material includes the ret $(644,972,544)$;
numerical radix value (integer constant) for Gamma-umma- $u t$ and how the name of the interval that the note makes with Gamma-ut and how

tabula furrarum, see Gushee, p. 138. The tabula has ${ }^{29}$ For a black-and-white photograph of the tabula fyuranum, see Gushee, p. I38. The to Scriplores been reproduced twice in quasi-facsimile: it forms the lower 1784) (hereafter GS, iii, and was ecclesiastici de musica sacra, ed. M. Gerbert, 3 vols. (St. Blasien, I785) St. Paul im Lavantthal in reproduced for $O$. Koller, 'Aus dem Archive des Benedictinerstiftes $S t$. Paul ind lated insertion Kärnten', fornat Koffe fir Musikgeschichte, $22 / 3$ (1890), pp. 35-45, as an unpaginated inserion relating to Monatshefte fuir. Ausikgeschichte, is entirely accurate, nor does any of these three relating to p. 40 . Neither facsimile is

reproductions indic 


\section{Peter M. Lefferts}

to calculate its integer value; the integer value itself and the resulting integer difference between successive pitches; the letter name (A-G) and additional comments; the Greek pitch name in the systema telion, with some neologisms; and another integer associated with the Greek pitch name, modified from Boethius, Book $4 .^{31}$ Some vocabulary and general concerns link this data closely to Jacques de Liège, and Gushee points to an exact correspondence between the forty-eight-note gamut of the Tabula monochordi and a table of forty-eight notes in a Catania manuscript. ${ }^{32}$ The total number of unique intervals upwards from Gamma-ut in these tables, removing octave transpositions but allowing for both $A \#$ and $\mathrm{C} b$, is, surprisingly, not quite as extensive in terms of interval variety as in the Speculum musice or the English material. (See above, Table 1).

Together, the chromatically saturated gamut of the tabula figurarum and the interval data of the tabula numerorum can be related to the causa generationis (pitches) and the causa exemplificationis (intervals) respectively. We unfortunately lack any knowledge of the generating mechanism. Nicolaus may well have employed a rational process to come up with this gamut, perhaps by a method not far graphic rem that of Boen. Perhaps - given his chosen means of the gamut from climbingt from Gama-ut to ee by lyma and comma. Of course, 列

${ }^{31}$ Ibid., pp. 143-50.

fol. $116^{-\mathrm{rv}}$. The Cate Riunite Civica e Antonia Ursino Recupero, Ursino Recupero D.39. Treatise, $\mathrm{Tp}$. $\mathrm{D}$, format, the kind of 13947 . This material is linked to for Gamma-ut and data it transmits, some technich the tabula numeronm by its tabulus Greater and and $e \ell$, and a distinctive modificatioal details involving numbers, nomenclanter According Lesser Perfect Systems mof Grication to the names of notes as drawn from the by twding to James Haar, the table's peceek music theory (see Gushee, pp. 144, 149-50? fol the other treatises in the Catania s peculiarly unorthodox Greater Perfect System is shared (fols. $4 f^{-}-115^{\text {') }}$ that immediately manuscript, namely a version of the De musica of Boethins Further, the De musica and the Su precedes the table, and a Summa Boecii (fols. $155^{\mathrm{va}-156^{\text {th }}}$ Comentum super cantum of the Summs are linked to another treatise in the same manuscript, the precedes the Summa by Englishman Roger Caperon (folse in the same manuscript, the Gamma-ut (comuff) in the unusual terminology for the top pit interrelated and Haar, 'Roger Care the closest known these four treatises in the Catania manuscript are further noger Caperon and Ramos kanship to the tabula figuranum and tabula numeronum. (Ste earlier morow thread concerning da Pareia', Acta Misicologica, 41 (1969), pp. 26-36.) At and tabonochord treatise to the Cwelve dieses (minor semitones) per octave that binds an Contribla numerorum of Nicolaus) iatania table (and thus, I might add, to the tabula fimuranth

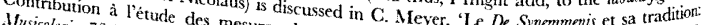
Mtusicnlogie, 76 (1990) pp. 83 mesures du monocorde Meyer, 'Le De Synemmenis et sa tradtion do
A Riddle and a Song

$\mathrm{C} b$, only one of which ought to have been necessary, and why there is not full octave equivalence. Extending Boen's method, as was done above, shows us how there could be a method yielding both $A \sharp$ and $C b$, in different octaves, but whether this would even have made sense to Nicolaus, as well as what might have dictated for Nicolaus the choice of acute $c b$ over acute $a \sharp$, remain open questions.

\section{Cancelling accidentals}

Leaving aside pitch collections for the moment, let us turn to the second issue provided by the ballade's tonal behaviour, namely its method of cancelling accidentals by letter names. All other examples of this method known to me are also in English sources. The earliest are two isolated later fourteenth-century score format settings in discant, a Kyrie and the hymn Gloria laus et honor. ${ }^{33}$ The third example is found in the English material on intervals from Reg. Lat. 1146 and Lansdowne 763 already mentioned above. Finally, letter-name cancellation is not uncommon in English fifteenthcentury music sources, including, for example, the additions to the Old Hall manuscript made by second-layer scribes, and the English sources of Dunstable's music. ${ }^{3+}$

${ }^{33}$ The Kyrie is in Pisa, Biblioteca Cateriniana del Seminario, MS 176, fols. $217^{\mathrm{v}}-218$. For a facsimile, see English Fourteenth-Century Polyphon: Facsimile Edition of Sources sotated in Score, ed. W. J. Summers (Tutzing, 1983), plates 209-10. It has been edited in English. Music for. Mass and Offices, i, ed. F. Ll. Harrison, E. H. Sanders and P. M. Lefferts (Polyphonic Music of the Fourteenth Centry Glonia laus et honor is in Century, Surm in worcester, Cathedral Library, MIS Additional 68 , Fragur for the Fourteenth Cummers, 'Unknown and Unidentified English Polyphonic Music from the Foun. 4. For Century', Royal Mfusical Association Research Chronicle, 19 (1983-5), pp. 57-67, at p. 63, n. 4. For a good image, see the Digital Image Archive of Medieval Music (online at <http:// www.diamm.ac.uk>), where the page is identified as Frag. xix, fol. $3^{v}$. For a poor facsimile in which the cancellation letters are unfortunately not visible, see Worcester Add. 68, Viestminster Abbey 33327 . (Publications of Ladrid, Bibl. Nac. 192: Facsimile, Introduction, Index and Transeriptions, The Itotcester of Mediaeval Musical Manuscripts, 5; Brooklyn, I95 Documents, 2; Rome, 1957), no. 86 .

See M. Bent, 'The Old Hall Manuscript: A Paleographic Study' (Ph.D. thesis, Cambridge University, 1969), pp. 133-46 and 407. One further example is a previously overlooked fifteenth-century score-format three-voice discant setting in void notation (with unidentified cantus firmus in the lowest Bodleian Librar; US Latin liturg of a thirteenthcentury music manuscript liturg. d. 20, fol. 35") that was originally part The music was apparently entered before the original codex was dismembered. 


\section{Peter M. Lefferts}

In the ballade, it would appear that accidentals hold (inconsistencies aside) either until cancelled or until the end of (inconsismusical unit. Of greater significance, the inflection applies to the is no note but does not carry the logic of the hand. That is, there example, $D \#$ of any wider hexachordal environment. For automatically, even if the singer might call it $m i$, does not here automatically invoke a hexachord built on B-ut with $\mathrm{C} \#, F \sharp$ and $\mathrm{G}$ for instically available as $r e$, sol, la. Nor does the notation of an $E$, $\mathrm{G} b$, whereas if cancel the $\mathrm{G} b$. hexachord built That is because if $\mathrm{E} b$ were solmised as $f a$, a

Rather than on $\mathrm{B} b$ as $u t$, with $\mathrm{G} \not$ as $l a$, would be implied. location of the merely functioning as the passive marker of the and flat signs upper or lower member of a half-step interval, sharp This gives them function actively as the agents of pitch change. its diatonic pitch roles to play. Each can pull a note away from semitone), and location (upward or downward by a major the diatonic pitch. A can cancel the effect of the other by restoring can have one of A note, while remaining in its clavis (say, acutes) surprisingly, a theorist different pitches or cordae $(g b, g, g \sharp)$. Not sharp signs, with vivid who describes this new agency for flat and 'And as much as vivid language, is Johannes Boen, in his Musictu' same degree a followintera distorts and disorders a note, so to the that note, and following littera can relocate and put back in place quantum una littequently lead it back to its usual station' ("Et sequens littera tittera notam extorquet et distemperat, tantum suam proprium mansion et retorquet et per consequens reducit ad name but accidansionem'). ${ }^{35}$ By littera Boen here means not letter namely $b$-quadratum and - and of course, these signs are letters There are at least $b$-rotundum.

agency for flat and two immediate consequences of this kind of subtle. The more sharp signs, one more obvious and one more double sharps or obvious consequence is that one cannot write only act once; a second flats. That is, the flat sign, for example, can less. (A note can only be stretchould only be redundant or meaning3i. 523

3.
A Riddle and a Song

$\mathrm{D}$ can be tugged up to $\mathrm{D} \sharp$ or down to $\mathrm{D} b$, but to nowhere else.) And Boen ponders this fact, with music examples. ${ }^{36}$ The more subtle consequence is that you cannot notate two consecutive major semitones, an observation with interesting resonances in Jacques de Liège's proposal of a tonus maior containing two major semitones, which he also regarded as impossible to notate. ${ }^{37}$

To advance the art beyond Boen's position requires the ability to assign an unambiguous single meaning and effect to the signs for lowering and raising. For this to be possible, one of their functions needs to be removed, and this is most naturally the power to cancel a sharp or flat, restoring a note to its natural pitch. That function is precisely what has been taken over in our English sources by the use of the letter name as the sign of cancellation; the letter name is akin in function to the modern natural sign. And most tellingly, in the interval examples of Reg. Lat. 1146 and Lansdowne 763, this way to indicate cancellation is precisely what allows the writing of consecutive major seconds in the same clavis $(\mathrm{G} b, \mathrm{G}, \mathrm{G} \#$; $\mathrm{Ab}, \mathrm{A}$, $A \sharp)^{38}$ Thus both in pitch content and in the implications of its method of cancelling accidentals, our ballade is just a step beyond Boen's position in the mid-1350s.

\section{THE TEXT: THE REFRAIN LINE}

What light does the text shed on this tonal behaviour? As in any ballade, the place to begin to examine the text is the refrain line. We would hope for it to make sense for all six stanzas, but it would not be surprising if it were tailored more closely to the opening three of our double ballade, in the assumption that they were the first to be written. ${ }^{39}$ The two sources of our text disagree over the first word of the refrain: Bodley 842 has tribulor, while Rome/St. Paul reads, with

37 Ibid., p. 59, ex, 3, 4, 5 et passim.

Speculum musice, ed. Bragard, be, 2 cap. XIII (ii, p. 104); see also Gushee, pp. 147-8. The impossibility of notating two major semitones is Boen's corollary to his fourth conclusion 38 concerning the effects of flat and sharp signs (Musica, ed. Frobenius, p. 59).

The letter $A$ is alsocts of hat and sharp signs (Mustica, ed. Frobenis, p. raise Bb to Bq. That is logical if there is no $B \#$ in the system: the sharp sign can be used to cancel in a claits with two cordae.

Each of the first three stanzas has exactly twenty-two words, while the subsequent three have nineteen, seventeen and twenty-two words. The internal consistency of word counts may indicate the priority of the first three stanzas. My thanks to Thomas J. Mathiesen for this observation. 


\section{Peter M. Lefferts}

light amendment, cribrorum. In abbreviated form these two word would be very closely related palaeographically, and it is suret credible that one could have emerged from a misreading of the other; alternatively, they may both be misreadings of some other word, probably a relatively unfamiliar one, that scribes were having trouble with.

Tribulor itself is not a common word, but it is biblical (Psalms 30: 10, 68: 18, 101: 3 and Lamentations of Jeremiah 1: 20), and it is therefore also found in biblical commentaries such as those br Augustine of Hippo and Cassiodorus. In these contexts it is a passive verb in constructions like 'quoniam tribulor', where the psalmist calls out to the Lord 'because I am in distress'. If tribulor is indeed a who causes it may be a corruption of turbator, something or someone could put into the who stirs things up. In any event, our refrain and ballade the mouth of the singer the sentiment that the poem overtones of distrexing, discomforting or challenging. The biblical too seriously, they may be intentional, and especially if not taken and the sophistication be appropriate to the difficulty of the text The refraintication of the composition.

A cribrum is a line in Rome/St. Paul reads Cribronum demonstracio. made in the tool for sifting dry material like grain and is usually wooden frame 40 of a wire lattice secured inside a rectangular riddle (as a tool, ${ }^{40}$ The word is rendered into English as sieve or a dry measure, a riddle is a coarse-meshed sieve); it can also mean literally, that i.e., a sieveful. Thus the refrain might mean, most relates cribrum to is a demonstration of sieves. Lawrence Gushee staff system the sieve-like appearance of the twenty-four-line has observed the tabula figurarum, ${ }^{41}$ and Leofranc Holford-Strevens drawn from the me that in Bodley 842, the way lines have been the words are end of each verse to the refrain makes it look as if extension, to the into a sieve. Thus cribrum may simply refer, by musical staff. Since cribrorum is a plur Aribrum could be

sheets. Technoly thanks for Prof. Benf ${ }^{4}$ Gushee py, University of Toronto, Institute for the History of Philosophy of Science an figurarum of Nico. Gushee assumes that the poe references (private comm.).

in aram of Nicolaus de Ludumes that the poetic text add (private comm.). staff itself.
sroduce something that makes sense', for filtering out some of the notational sign
s.
A Riddle and a Song

form - multiple sieves, or perhaps the yield of multiple siftings - we need to find an explanation appropriate to its plurality. At the very least it might refer to multiple staves; as another possibility, we may need two sieves, one for tonal and the other for mensural behaviour.

The term first occurs in two much earlier Continental music treatises, the Musica (before 1068) of Wilhelm of Hirsau (d. 1091), and the derivative Mensura quadripartite figure of Otker of Regensburg (fl. eleventh or twelfth century). In both, cribrum monochordi is synonymous with theorema troporum, referring to a figure that explains the varied tonal content and interrelationship of the melodic modes by means of tetrachords and the staggered alignment of four or five diagrams of the gamut, producing a dense thicket of lines at right angles to one another resembling a sieve. In Otker's treatise and in the De musica of another nearby German contemporary of Wilhelm, Aribo of Freising (fl. 1068-78), this grid is also called by the name quadripartita figura. ${ }^{42}$ This German material, although not the specific term we are seeking, is still being addressed in the fourteenth century. ${ }^{43}$ Although the monochord of Wilhelm's expression cribrum monochordi is simply the diatonic gamut as derived via the monochord, his sieve is a tonal sieve, and it is certainly within the realm of possibility that the term was borrowed and the concept somehow extended to help conceptualise chromatic additions to the gamut.

${ }^{12}$ For Wilhelm's figure, see Willehelmus Hirsaugensis, 1fusica (GS, ii, pp. 15+82) at figure B between pp. 164 and 165, and IVillehelmi Hirsaugensis Musica, ed. D. Harbison (Corpus Scriptorum de Musica, 23. [Rome] 1975), 38. For Otker's figure, see Otkeri Ratisbonensi Monachi aetatis incertae Regensburg', incertae mensura quadripartitae figurae, GS, ii, p. 34, and) [Naw Groie $l$ ], xviii,

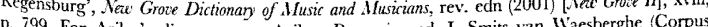
p. 799. For Aribo's diagram, see Aribo, De musica, ed. J. Smits van Waesberghe (Corpus Scriptorum de Mlusica, 2; [Rome], 1951), p. 4, and for both diagrams, see A. Hughes, 'Aribo', New Grore II, i, pp. 897-8, at p. 897. See also L. Bronarski, 'Die Quadripartita figura in der mittelalterlichen Musiktheorie', in K. Weinmann (ed.), Festschrift Peter Wagner zum 60. Geburtstag (Leipzig, 1926; repr. Farnborough, 1969), pp. 27-43, with the diagrams of Otker and Arito reproduced at pp. 32-3. The lineage of his kind of diagram can be traced back to Boethius, De musica, bk. 4 .

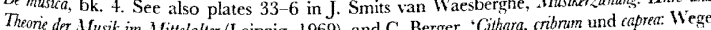
zum der Musik im . Mittelalter (Leipzig, 1969), and C. Berger, 'Cithara, cribrum und caprea: Wege zum Hexachord', in M. Kintzinger, S. Lorenz and M. Walter (eds.), Sctule und Schitler im Mittelalter: Beiträge zur europäischen Bildungsgeschichte des 9. bis 15. Jahrhunderts (Neimar and Vienna, 43 1996), pp. 89-109.

The diagram is reproduced by Jacques de Liège when he quotes from Aribo in bk. 6, cap. LVIII of the Speculum musice reproduces the two elements of. Bragard, vi, pp. 158-9. Furhersoris Susica $(1+10-11)$ as his 'monochord of the eight monoch of the eight modes' and 'monochord of the nine maks', ceference to cribrum and aserd of monochords (monocordum monocordonum). Ciconia makes no relerence to cibn $D_{2}$

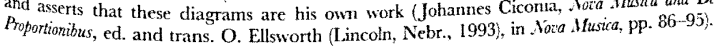




\section{Peter M. Lefferts}

The only appearance of cribrum in medieval English music theor that I have found is in the title 'Cribrum proportionum', used in a later fifteenth-century manuscript to identify a triangular diagram of proportions. ${ }^{44}$ In this figure, a series of uniformly spaced lines rising These lines intersect within triangle is drawn parallel to each side. in whose diamond-shithin the triangle to form a symmetrical lattice proportions that to 10 . Cribrum is can be represented by the whole numbers from I the context is is obviously being used here in the sense of 'sieve', and than Wilhel surely less pertinent to the behaviours in our chanson

This

Gushee points to however, close the issue of the term cribrm familiar to mathemation of cribrum that would have been sieve of Eratosthematically astute musicians, in the expression the theory, a methodenes' ${ }^{46}$ 'This sieve is a bit of elementary number out all multiples of finding primes in a set of numbers by striking of 5 beyond 5 of known primes (of 2 beyond 2, of 3 beyond 3 Eratosthenes (fl, and so forth). The method was invented by in his Introductio arithm-195 $\mathrm{BC}$ ), described by Nicomachus of Gerasa by Boethius, whose arithmetica, and transmitted to the later Middle Ages adaptation of $\mathrm{Nic}$ De institutione arithmetica is a Latin translation and

\section{${ }^{44} \mathrm{Ca}$}

College sub-librarian College, MS R.14.52, fol. cclvir ${ }^{\mathrm{r}}\left(256 \mathrm{~b}^{\mathrm{r}}\right)$ I would lite to thank the Trinit photocopy of this folio. Thon Sproston for her generous ). I would like to thank the Trinit sources an identical o. The triangulum proportionum is fol. $56^{*}$, where is is one appears, for example, in Camot an unfamiliar diagram. In English related figure appers inelled 'Figura proportion Cambridge, Trinity College, MS O.9.29 (London, 1597) appears in Thomas Morley, tions of the wh), p. 33. A similar but larger A Plaine and Easie Introduction to Practicall Mussiti fol. 2 . whe numbers from l larger and unlabelled figure representing the proport5. 2 . 2 .

of the term ince to any earlier instances, Gusee a 'Musical sieve fitle of Marco Scacchi's Guibee (p. 140, n. 33) mentions the much later use a conter sieve for the Syfert wheat' hat Cribrum musicum ad triticum Siferticum (Venice, 16 43 . Szrieskowsorary. For more on Scat' that polemically enumerates the compositional errors of

th. Szrieykowski, 'Scacchi, Marco' New Ground this publication, see C. V. Palisca and Z. I. Gushee makes this observation (p. 140 , II, xxii, pp. 363-5.
independently allion, For the Nicomachus it to my attention.
R. H), and I thank Leofranc Holford-Strevens for

Anthmetic (Neipzig, 1866), trans. M. I Geraseni Bthagorei Introductionis Arithmeticae Libri II, ed.

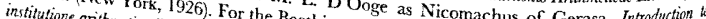
G. Friedle

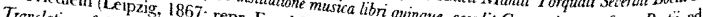
Translation of the De Instivu; repr. Frankfurt, 1966), quinque, accedit Geometria quae fertur Boetia, ed. tudies in Classical Antiquity, 6; Amsterdam, 1983:
A Riddle and a Song

Its citation by Boethius is sufficient guarantee of its familiarity, but later authors refer to it as well. ${ }^{48}$

Of what relevance is this to us? Well for one, we do not need Wilhelm's cribrum monochordi to evoke a sieve. Moreover, the mathematical context of the expression resonates with other language of number in our lyric, as we will see in a moment (calculus, racio, rata). Perhaps the cancellation of non-primes is meant to be associated with the cancellation of accidentals. Less obviously, prime numbers are incomposite (not able to be factored) in Boethius' terminology in the Arithmetica, and the trihemitonium of the chromatic tetrachord (of which more in a moment) is incomposite (not compounded of smaller intervals) in Boethius' terminology in the Musica. Thus even if specific prime numbers are not what we should be looking for in our ballade, an indirect suggestion of mathematics and some shared terminology of mathematics and music theory might well be intended by the word cribrum.

I cannot restrain myself from floating one further remote speculation. If the Latinate author of our poem was a native speaker of English, he may have intended a pun here. In English, then as now, there are two meanings of riddle with entirely different etymologies: as sieve and as puzzle (conundrum, problem, mystery). Further, a riddle is a 'dark saying' or 'dark speech' (obscure, indistinct, veiled), a colouring that is also strongly associated with enigma, a word with which puzzle is often paired. ${ }^{49}$ The Oxford English Dictionary, 2nd edn, defines enigma as 'A short composition in prose or verse, in which something is described by intentionally obscure metaphors, in order to afford an exercise for the ingenuity of the reader or hearer in guessing what is meant' 50 This could easily describe Ut pateat etidenter. Darkness, in turn, may pun on the darkening - the coloration - of our ballade's chromaticism. ${ }^{51}$

${ }^{40}$ Boechius, Inst. Arith ed Friedlein, I xii, 20-1 (p. 33): "quam scilicet Eratosthenes cribrum

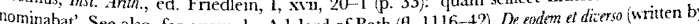

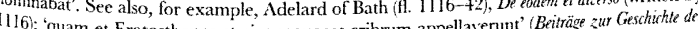
Phitosophio des et Eratosthenes et ejus sequaces cribrum app

* Philosophie des. Mittlalters, IV/i (1903), pp. 3-34, at p. 25).

Sec Oxford English Dictionary entries for enigma, riddle and sieve, where Latin-English word lists 50 equating the terms cribrum and riddle are cited.

See the Vulgate Old Testament at Numbers 12:8 ('per enigmata') and the New Testament at 1 Corinthians 13:12 ('in enimt at Numbers 12: ("per enigmata') and the

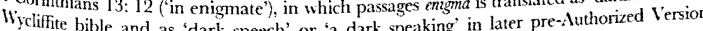
translations.

The chromaticising of musical figures is a shading, tinging or darkening; the concept mixes sight and sound. The reference need not just be to the effect of lowering and raising, but may 
This move from sieve in Latin to riddle in English as tool and on to riddle as enigma is quite a stretch, I will admit. In the end, whatever the first word of the refrain was intended to be, the poem is a challenge directly thrown out to the reader, self-consciously announcing its intention to be difficult and to mean more than it says outright. The humorous irony of the first line ('Ut pateat evidenter') cannot be missed, and a cross-eyed portrait illuminating the ' $U$ ' of ' $U t$ ' in the St. Paul fascicle may be intended to reveal perplexity at this manifestly confusing text.

\section{THE TEXT: STANZAS 1 TO 3 AND TONAL BEHAVIOUR}

Turning now from the refrain line to the first three stanzas, which refer to tonal behaviour, the first thing that needs to be said is that their language is difficult. Of course this can now be understood as deliberate, although one suspects that their intentionally puzzling nature is exacerbated by the demands of the rhyme scheme and syllable count, as well as perhaps by a lack of native poeticising talent. On the other hand, there are aspects of language and versification that suggest a very sophisticated mind at work. To begin with, we have a complex syntactic strucure in which a single sentence runs through all six stanzas, governed by the imperative form of a 'knowing or thinking' verb, puta (line 16) and its requisite passive infinitives of indirect statement with subject accusative, pandi (line 8) and dari (line 24). The refrain line does not seem to be integrated syntactically, but rather operates as a parenthetic comment, except perhaps, as in the present translation, in the fifth stanza. In classical Latin, puto has arithmetic overtones of counting or computing in addition to the sense of pondering or reasoning, and mathematical connotations may have influenced the choice of this particular verb. Indeed, as in any good riddle we will see that the author has left obvious clues in catch phrases and word associations that would have illuminated his meaning more readily ferreted out all audience than for us today. I make no claim to have ferreted out all of these clues.

also refer to the use of additional (black) notational signs. The sixteenth century's madrigath
cromatici are $a$ note nore because hes Italy, 1535-50', New Grove $I I, x y$, p. 550 .
The first stanza is relatively straightforward in meaning and declares its intention openly. It asserts that one can generate on the monochord many pitches beyond the ordinary medieval gamut that are possible to represent on the staff, and through arithmetic one can compute their values. They are different, yet still beautiful, and can be sung by the many who do not understand their underlying mathematical justification. Clearly, this stanza alone would be enough to prompt the association of ballade text and Tabula monochordi, and it might possibly have been what caught the eye of whoever brought them together.

The expression 'ut calculi fert racio' (line 6) directly evokes medieval treatises on calculation. ${ }^{52} \mathrm{By}$ it we are reminded that musical pitches have numerical values and that such knowledge of the numbers underlying the everyday world distinguishes the learned man from the ignorant. (Implicitly, the musicus/cantor dichotomy is being invoked.) Isidore offers a classic statement of this general sentiment in the section concerning the importance of number, 'Quid praestent numeri' ('What do numbers show'), from Book 3, De Mathematica, of the Etymologiae. This passage undoubtedly affected our poet's choice of language, especially via its concluding peroration, which is as follows: 'Remove numbers from all things, and all perish. Take away computation in this world and all will be enveloped by blind ignorance, nor can man be differentiated from the other animals, who are ignorant of an understanding of calculation' ('Tolle numerum in rebus omnibus, et omnia pereunt. Adime saeculo conputum, et cuncta ignorantia caeca conplectitur, nec differri potest a ceteris animalibus, qui calculi nesciunt rationem'). ${ }^{53}$ The concluding words not only use calculus and ratio but also the nescio of the ballade's nescienter.

Stanzas 2 and 3 share the vocabulary of 'old and new' and 'colour'. It is unclear just what the new and old are (nota, figura, forma, signa?), but the available feminine plural that is the most obvious

52. Calendrical computations are justified 'de ratione calculi'. See Patrologia Latina, xxrii, pp. 1004 and 1178 ; further, a little treatise sometimes attributed to Bede is the Libellus de ratione calculi (see Patrologia Latina, a little treatise sometimes attributed to Bede is the Labellus de ratbne that in 'both classical and medieval 677). More generally, Alexander Murray has observed hat in the derivatives medieval Latin ... racia appeared with other terms - computus, calculis, and their

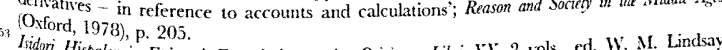

SYidori Hispalensis Episcopi Etymologiarum size Originum Libri XX, 2 sols., ed. W. M. Lindsay (Oxford, $191 \mathrm{I}$ ), i, Lib. 3, Cap. 4. 


\section{Peter M. Lefferts}

referent is corda (cordis, line 5), invoking the monochord. If one thinks of strings, the visual aspect is not so different from the staff, but corda refers to one individual pitch, in opposition to the lines and spaces of the staff (typically, claves, or lineas et spacias), each of which may be the location of more than one pitch. Boen calls the diatonic genus cantus communis, a unique designation so far as I can ascertain, which affirms the common-sense reading of stanza l's 'diversis a communibus cordis' (lines 4-5) as unusual chromatic tones. These new pitches are a recent phenomenon. The old are most likely the standard notes of the diatonic medieval gamut; the newer but not very newest notes would be more familiar yet unstandard chromatic notes, such as perhaps $\mathrm{F} \sharp$ and $\mathrm{E}$. .

Colour issues begin with the matter of black lines and white spaces, the nigris tractibus and marginibus albis of stanza 2 (lines 9-11). This is unique terminology if, as in my translation, what is being described are the lines and spaces of the musical staff. ${ }^{54}$ Margo most commonly means margin or border, and in music notation tractus usually refers to a vertical stroke on a notehead, so as an alternative we might translate margo as staff and tractus as musical note. The principal difficulty with this reading can be framed as a question: why is the staff described as white? Nonetheless, surprising support for it can be found in a much later vernacular English musical proverb of the early 1520 s from Leconfield Manor that also associates pureness, whiteness, margins and monochords:

Musyke hath her coloures of dyuersites

Black voyde, black full. alteraciones of curiosite

But the white is more comely and to clennes doth accorde

For purenes in the margent makithe a trew monacorde.

Of virginall color moste comely in armys the syluer shene

In musyke purenes whiche is farrest seane

In musyke makithe melody soundynge from all blame

Of the whiche shynythe the clere voce of a pure name

The margent sylver and the notis sabill

Shulde move vs to remembrance of the Joyes Intermynabill. ${ }^{5}$

The only reference I can find where margo may be technical jargon for a space in a staff is in in GS … G. (Ottawa, 2001), p. 28: 'Vides 326, and Peter Slemon, Introductorium musicae of Johannes hith marginum lincarumgue interpositiono sonorum proportiones secundum locorum distantiam /

5.; 'by boundaries and interposed lines' ( $\mathrm{p}$. emphasis). Slemon translates the last four words as See E. Flügel, 'Kleinere

and Enformacion; Die Provelungen aus Handschriften: Cornyshe's Treatise bitwene Tronth and Enformacion; Die Proverbs von Lekenfield und
A Riddle and a Song

The proverb describes the margin (staff) as white (silver) and notes as black (sable). Very possibly, given the musically conservative tone of the Leconfield proverbs as a whole, white's purity and cleanness refer to diatonicism - a lack of chromaticism. Black in this reading could then refer, at least in part, to chromaticism ('coloures of dyuersites').

Such vernacular English support for my alternative reading, coming as it does a century and a half after the creation of our ballade, does not dissuade me from preferring my original interpretation of tractus and margo and as line and space, however unusual a choice of words this may be. As I understand what is being said, the author is creating a parallel between black and white, line and space, so that he can place chromatic notes in an imagined space between them. These notes are intermediate colours, variously tinged. ${ }^{56}$ Further, our author is positive about this innovation. He likes the distinction of new from old, of the chromatic from the diatonic, and through his choice of the word distinccio in stanza 2 (line 13) he also introduces a connotation of decorative beauty.

This inbetweenness prompts a number of observations. First, our author presumably counts $\mathrm{B} b$ as a chromatic inflection no longer neutrally occupying the same clavis (line or space) as $\mathrm{B} \not$ but rather in a sense bending or pulling that clavis down towards the adjacent clavis below, to use Boen's concepts here, encouraged by the fact that Boen privileges $\mathrm{B} h$ (prestantior sit) over $\mathrm{B} b$ in just this way. ${ }^{57}$ Furthermore, all these new pitches create a tension between corda and clavis, since there are more cordae than clazes. These new pitches can be explicitly represented only on a monochord or in diagrams

p. 479. I owe this reference to R. Woodley, John Tucke: A Case Study in Early Tudor. Atusic Theory (Oxford, 1993), p. 119, n. R. and thank Dr Woodley also for providing me with his unpublished 1998 conference Leconfield proverbs are closely related to the earlier Parable beticeen Information and 1/usic in the 'Treatise' of William Core symonymous with musical staff (Flügel, p. 470).
sych

Such a reading suggests a resolution to one difficult textual crux at line 19. The second word may be read with initial s or $f$ and medial $c$ or $t$, and with or without an $r$ following the disputed medial consonant: thus sustis, sustris, fustis, fustris, etc. The locution fustris langentibus could be read as 'touching the note stems (or staff lines)'. Leofranc Holford-Strevens has suggested to me the reading frustis, from frustum (fragment) which has the advantage of perhaps referring to sieve (are the fragments frustum (fragment), which has the advantage of pertment in the spirit of "colour', I have adop those that remain in the sieves.). As a bolder anch has the advantage of a direct I have adopted fuscis, from fuscum (dark, dyed, blackened), which has the adve below), and which has prompted me to thadition of Aristotelian colour theory (on which see below)

Boen, Alusica, ed. Frobenius, p. 52 . 


\section{Peter M. Lefferts}

like the rota compositionis monochordi and tabula figurarum of the Rome/St. Paul manuscript. A monochord effectively grants each pitch its own corda, while the tabula figurarum creates for every pitch its own new clavis. Although our author ignores the Guidonian hand and hexachord as a means of representing and navigating through tonal space, by retaining Guido's staff he must face the incompatibility of corda and claris, which he does by emphasising inbetweenness as a way of imagining just where the new pitches are. The ballade's lyrics and music work together to characterise this fundamental problem and offer both practical and theoretical solutions to it. 58

It is clear that the first three stanzas are not a black and white text, and to begin to explore their grey areas - to enrich our understanding of the intellectual contexts possibly being evoked by our enigmatic riddle and thereby possibly to understand our ballade better - it will be helpful briefly to explore some of the multiple meanings that color bore for medieval readers in respect to the visual spectrum, musical chromaticism and rhetoric. ${ }^{59}$

\section{Colour referencing the visual spectrum}

For a starting place in an exploration of the resonances of colour, there is of course its most concrete sense, as a visual perception. The standard medieval theory of the visual spectrum is that colours lie along a continuum between black and white, mixing the attributes

\footnotetext{
${ }^{58}$ By championing the monochord over the hand and hexachord, our author stakes out a position with important parallels to that of Ciconia in the Musica Nora (1410-11). Ciconia avoids the use of Guidonian solmisation syflables in his the Musica Nova (1410-11). Ciconia hexachordists whom he calls Guidoniste (followers in his treatise and repeatedly critiques thos Iova, ed. Ellsworth, pp. $302-5$ ): 'If one wishes to Guido), as in the following passage (1tust select one of two things: either the hand, like the Guidonists, or the music .... one should the good teacher, never misleads ( $\mathrm{Si}$ quis cantume the Guidonists, or the monochord, which, hle Aut computum, ut Guidoniste, aut monocon musice scire ... Post hec unum e duobus elig thanks to Stefano Mengozzi, for directing my, qui numquam fallit, ut bonus magister). See Mengozzi, 'The Ciconian directing my attention to Ciconia's position on these matter transition (Turnhout, 2003), pp. 297-301.', in P. Vendrix (ed.), Johannes Ciconia, musicien de For uses of color in medi), pp. 297-301.

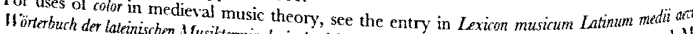
Bernhard Mfunich, 1992 ) interminologie des. Mittelalters bis zum Ausgang des 15. Jahrhunderts, ed. Y in Geschichye und C, 1992-) in fasc. 5 (2001), cols. $550-9$ See also G. Reaney 'Color', Dhe Itwe II, vi, P. I55 Gegenwart, it (1952), 1566-78; E. H. Sanders and M. Rindley 'Color', Mirc Gro (eds). Jus, and G. Boone, 'Tonal Color in Dufo', in and M. Lindly, 'Colo', Cumming

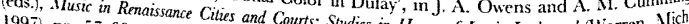
1997), pp. 57-99.
}

A Riddle and a Song

of blackness and whiteness in varying degrees. Red, for instance, lies half way between black and white, and blue lies between red and black; further subdivision of the red-black limb of the spectrum yields purple and green. Because of their intermediateness, visual shades are variously referred to as colores medii, intermedii, medietates, mixti, secundarii, collaterales, and so on. Thus the mediis coloribus (line 12) and colore vario (line 20) of our poem invoked a familiar meaning for the alert medieval reader.

For the Middle Ages, this doctrine had its roots in Aristotle. Its most explicit sources in the philosopher's writings are twofold: passages on contrariety and passages on sensible qualities. Concerning the first of these, Aristotle recognises contrariety as one of the four kinds of opposition. White and black, being contraries in the same genus - a genus in which there are intermediates derived from the extremes - are his single most frequently invoked example of this relationship. The white-black comparison surfaces frequently in almost all his major works, but the principal locus for the material is the Categories, one of the best-known Aristotelian works in the Latin Middle Ages. The main discussion is in chapter 10, concerning opposites that are contraries, which is found at $11^{\mathrm{b}} 32-12^{\mathrm{a}} 25$. Here black and white are identified as opposite colours, between which are intermediates including dark and pale and all other colours ('fuscum et nitelinum et quicumque alii colores'). ${ }^{60}$

Concerning sensible qualities, the principal extended treatments are in On the Soul (De anima) and Sense and Sensibilia (De sensu et sensili) ${ }^{61}$ According to Aristotle the sensibles corresponding to each sensory organ are five in number (colour, sound, odour, savour, touch), and these naturally invoke contrariety, because 'contrarieties are

6i) For the various medieval Latin versions of the Categories, see Aristotle, Categoniae vel Praedicamenta, ed. L. Minio-Paluello (the passage with fuscum and nitelinum, (Aristoteles Latinus, I, 1-5; Leiden, 1961) [AL]. For thiam of Moerbeke AL, 'Translatiom, see the mid-thirteenth-century Latin translat we by and pallidim (AL, pp. 32-3), while the 'Euillelmi', p. 109); the 'Translatio Boethil' has . 70-1). There are other scattered the 'Editio Composita' has fuscum and pallidum (AL, pp. 70-1). There are other scattered references in the Categories. The white-black pair as an example of contrariety can perhaps be most easily traced through all of Aristotle's works via the general index of The Complete Works of Aristolle: The Recised Oxford Translation, ed. J. Barnes, 2 vols. (Bollingen Series, 1; Princeton, 1984). The theory of colour I am discussing is not developed in the pseudo-Aristotelian $D_{e}$ coloribus libelus sometimes attributed to Theophrastus (available as $O n$ ${ }_{61}$ Colours in Complete Works, ed. Barnes, i, pp. I219-28).

(1) mid-twelfth century'; C. Page, 'Reading and Reminiscence: Tinctoris on the Beauty of Nusic', Joumal of the American 1.usicalogical Society, 49 (1996), pp. 1-31, at p. 28. 
Peter M. Lefferts

extremes, and every object of sense-perception involves contrariety e.g., in colour, white and black; in savour, sweet and bitter, and in all the other sensibles also the contraries are extremes' ${ }^{62}$ It should further be noted that the species of sensible qualities are limited, for 'in all classes of things lying between extremes the intermediates must be limited' ${ }^{63}$ There are seven principal species of colour, thus white and black plus five intermediates - yellow, red, purple, green, blue - and 'from these all others are derived by mixture' ${ }^{64}$

Beyond direct knowledge of Aristotle in the later Middle Ages, transmission of Aristotelian colour theory by numerous other authors is easy to demonstrate. It is found in commentaries on the Categories, for example. ${ }^{65}$ The doctrine is familiar to Isidore of Seville and later encyclopedists. ${ }^{66}$ Another place to find late medieval colour theory is in treatises on heraldry, where some authorities attempted to reconcile the heraldic and Aristotelian tradition. ${ }^{67}$ And Aristotelian concepts and terminology even have a role in some treatises on music. ${ }^{68}$

62 Aristolle, De sensu, $445^{\mathrm{b}} 246$ (Complete IVorks, ed. Barnes, i, p. 707) example, at $422^{\mathrm{b}} 22-30$. has the extremes of high and low (or with savour the extremes of bitter and sweet, and soun extremes (it has more thand low (or sharp and flat), only touch lacks a single pair of oppose De anima, $421^{\mathrm{a}} 17,421^{\mathrm{a}} 27$ one, including hot and cold, dry and moist, hard and soft, etc.). See ${ }_{63}$ De anima, $421^{\mathrm{a}} 17,421^{\mathrm{a}} 27$ and $422^{\mathrm{b}} 10$, along with De sensu, $443^{\mathrm{b}} 7$.

64 Aristotle, De sensu, $445^{\text {b}} 23$ (Complete Works, ed. Barnes, i, p. 707).

Aristotle, De sensu, 442a 21-5 (Complete Works, ed. Barnes, i, p. 702). Barnes translates the intermediates as yellow, crimson, violet, leek-green and deep blue. See also G. R. T. Ros. Aristotle, De Sensu and De memoria: Text and Translation with Introduction and Commentary (Cambridgr 1906), p. 69, where the intermediates are translated from Introduction and Commentary (Cambrimspurple, green and blue. Just for the record in Work, ed. Barnes, ine Jeteorology, 372 $1-10$ and $375^{\text {a }} 1-20$ (Compti colours, in the order red, $600,603-4)$, Aristotle describes the rainbow as having only thre sometimes seen between red and green.
Boethius, for one, particularly enough he admits that yellow/orange is

Cateogries, for one, particularly elaborates the doctrine of medii colores in his commentary on Categones, $10^{\mathrm{h}} 12$. See Boethius, In categorias Aristotelis (Patrologia Latina, lxiv, pp. 159-93, a
p. 25j). p. 25̃).

treatment Ebmologiae, ed. Lindsay, ii, bk. 19, no. 28, 7-8. Colour theory receives an extended treatment by the great English Francisan $28,7-8$. Colour theory receives an exend propretatibus renum, bk. 11, 'De accidentibuscan Bartholomeus Anglicus (fl. 1230-50) in odoribus', in which ch. 5 is 'De colontibus scilicet de coloribus et saporibus sive liquoribus John Trezisa's Translation of Bartholorum mediorum generacione'. See On the Properties of Thins (Oxford, 1975), ii, p. 1276 . See, e

John Trevor), an Ende armis (shorty after 1394) of Magister Johannes de Bado Aureo (Bishop E. J. Jones (C), an Englishman, in Medieval Heraldy: Some Fourteenth-Century Heraldic Works. Co

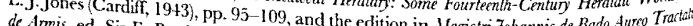

de Amis, ed. Sir E. Bysshe (London, and the edition in Magistri Johannis de Bado Aureo Tractem

One clear statement of classic colour theory in a late medieval music treatise is Ugolino of
Orvieto's Declaratio musicae discrpline
A Riddle and a Song

\section{Color referencing chroma}

If our alert medieval reader of the ballade text were also a well-schooled musician, especially of the fourteenth century, with its Boethian revival, an additional familiar, even automatic, association of color would be to chroma. There is a traditional locus associating visual colour, semitones, beauty (softness, sweetness) and inbetweenness with the chromatic melodic genus and the chromatic tetrachord. This synaesthetic blending of sight and sound was inherited by the Middle Ages from Greek music theory. ${ }^{69} \mathrm{~A}$ few details prove to be particularly relevant to the ballade's melodic language and also its invocation of intermediate colours.

The chromatic tetrachord consists of a perfect fourth (diatesseron) divided into three intervals: two adjacent semitones followed by an interval spanning three half steps (trihemitonium). According to Aristoxenus, the two independent semitones are equal (Boethius, Book V), while following Boethius (Book IV), they are a minor semitone and a major semitone. The Boethian division predominates in later medieval discussions. Though the largest interval measures a distance of three semitones, its internal structure is undefined; it is an unbroken span not understood as being compounded from smaller intervals in any specific order, and is thus described as incomposite. This is the one interval that is unique to the chromatic genus, and its status as the defining interval of the on red and void notes. See Uyolini Vrberelani Declaratio Musicae Disciplinae, ed. A. Seay, 3 vols.
(Corpus Scriptorum de Musica 7 ; Rome, 1959-62), ii, p. 201. Among other musical-theoretical Corpus Scriptorum de Musica 7; Rome, 1959-62), ii, p. 201. Among other musical-theoretical
instances, see also Anon. Summula tractatus metricus de musica, ed. E. Vetter (Divitiae Nusicae instances, see also Anon., Summula tractatus metricus de
Artis, A/VHIa; Buren, 1988), pp. 39-101, at p. 75 .

As an introduction to the topic, pp. 39-101, at p. 75 . articles 'Chroai' and 'Greece 1,3 (i)' in The New' Hanard Dictionay of M Music, ed. D. Randal (Cambridge, Mass., 1986), and 'Diatonik-Chromatik-Enharmonik' by P. Cahn in Die Musik in Geschichte und Gegen 1986), and 'Diatonik-Chromatik-Enharmonik' excellent and Gegemwart, 2nd edn (Kassel, 1991), proceeding for more detail next to the foum article by $\mathrm{A}$. Barbera, Arithmetic and Geometric Divisions of the Tetrachord, Joumal of .Music Theor, 21 (1977), pp. 291-323, and turning finally to readily arailable English translations of major Greek theorists. For the latter, see especially Greek. Musical Writings, ed. A. Barker, 2 vols. (Cambridge, 1984); Aristides Quintilianus, On .Music, in Three Books, trans. T. J. Mathiesen (New Haven, 1983); and Anicius Manlius Severinus Boethius, Fundamentals of .Muric, trans. C. M. Bower and ed. C. V. Palisca (New. Haven, 1989). Greek theory puts the largest interval on top when describing so that in the chrom describing the genera. Medienal theory at interval, sometimes as the lowernost. For an ine find the largest sometimes as the uppermost in terachords (mainly diatonic) upwards an introduction to medieval treaments of the spelling of tetrachords (mainly', pp. $1+57$. 
Peter M. Lefferts

chromatic genus was well understood by sufficiently sophisticated medieval and Renaissance theoreticians. ${ }^{70}$

Invocation of the chromatic genus might seem a bit of a leap, since this expression is not in our poem, but its status as a clue to our puzzle cannot be denied. The ballade, in fact, makes prominent aural use of the single most characteristic interval of the chromatic tetrachord, the trihemitonium. In our ballade this interval appears three times, in very exposed positions, in musical readings that we might otherwise be inclined to doubt, even keeping in mind the principal of difficilior lectio potior. Most assertive is the first such instance, the striking acute-register ascent from $c$ to $d \sharp$ at the opening of the cantus (bar l), which is immediately imitated by the tenor at the octave beneath (bar 1). This rising interval is mirrored considerably later by the descending acute $e$ to $d b$ in the cantus in the secunda pars at the end of section III (bar 23). I will return to the spelling of these intervals in a moment.

The lore of the melodic genera is derived from ancient Greek theory, and the detailed information on them that one finds in classical Greek texts is not, for the most part, a significant element in medieval Elementarlehre. ${ }^{71}$ But for the curious, ample detail was readily available in Boethius, De musica, and from Aristides Quintilianus via Martianus Capella. ${ }^{72}$ It is the requisite introduction

It is perhaps unexpected for a modern reader, although logical, that the semiditonus, rather than the two half-steps, is the uniquely defining feature of the chromatic genus; the modern equivalent is the unique role of the tritone in defining a major scale and key. On the integral or incomposite minor third as belon. 1 Iarchetto of Padua : (Chicago, 1985), A Critical Edition, Translation, and Commentany, ed. and trans. J. W. Herlinger est.' See also Ja) at 9.1.23 (p. 320): 'Omnis semiditonus in uno intervallo cromaticum gent exclusive associatio de Liège, Speculum musice, bk. 5, cap. 10, line 7 (ed. Bragard, v, p. 33). The notorive association of the minor third with the chromatic cons is at the cnux of Vicentino? notorious sixteenth-century debate about the chromatic genus is at the crux of nciml. Itssit

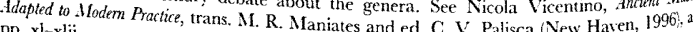
i K. $x$ l-xlii.

K.J. Sachs, 'Musikalische Elementarlehre im Mittelalter', in F. Zaminer (ed.), Rezeption ds Antiken Fachs im . Mittelalier (Geschichte der im Mittelalter', in F. Zaminer (ed.), Rezeption d, at 72 155.

for the musical inform of Aristicles Quintilianus, 'On Music' (c. $200 \mathrm{AD})$, was a principal source $425 \mathrm{AD}$ ) hich Quintiling wich read in the later Mrddle Arisite on the medies L. Gushee, 'Martianus Minneus Felix Cose. On Martianus and

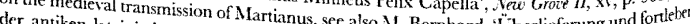
der antiken lateinischen Musiktheorie im, see also M. Bernhard, 'Überlieferung und forteber Fachs in Mittelalter, $\mathrm{pp}$. 7-35, It of Auxerre was another wartianus by Rem B. J. Tucker, 'Remigius [Ridely distributed source for this information; see L. Gushee and .

\section{A Riddle and a Song}

to $B$ b in many later medieval treatises, in a few of which the subject is revisited in great detail, albeit sometimes with more of a sense of obligation than of enthusiasm. Indeed, it is a commonplace of most later medieval theorists that the diatonic is championed as the only melodic genus in use, a point found elaborated in the fourteenth century, with its renewed interest in Boethius. (It is an observation especially applicable to the melodies of plainchant.) The rehashing of Boethius in the Quatuor principalia is characteristic. ${ }^{73}$ But where there is smoke there is fire, and the intensity of some reactions to the lore of the genera indicates that a contrary view championing the chromatic genus is being put forth elsewhere with significant force. Johannes de Muris, for instance, gives an elaborate outpouring in defence of the diatonic against more exotic possibilities in Musica speculativa (1323), an outpouring whose very prolixity carries the implication of special pleading. ${ }^{74}$

The principal sticking point to the admission of the chromatic genus into practice, beyond its irrelevance to chant, was its inability to be notated in staff notation. And here the semitones are the responsible party, or to be more precise, the major semitone. The trihemitonium can be located in many places, and the minor semitone has several locations as well. But the major semitone is only found at two locations, acute $b-f a-\#-m i$ and superacute $b b-f a-\# \#-m i$, and a prohibition against direct melodic chromaticism (singing $\mathrm{B} b$ and $\mathrm{Bh}$ consecutively), usually expressed as a prohibition against mutation in this clavis, is standard. Jacques de Liège allows a window of opportunity, relaxing this stricture though admitting that the situation is not common. The chromatic genus is not musica falsa per se, but the two are related contextually at $b-f a-\#-m i$. For Jacques, the chromatic tetrachord is the standard Boethian variety with minor and major semitones, and if it is to be written in the traditional gamut, it must be located at A, B b, B, D (see Example 1a). ${ }^{75}$

\footnotetext{
Quatuor principalia, ed. E. de Coussemaker Scriptonun de musica medii aeci noza series a Gerbertino altera thereafter CS 4 . de Coussemaker, Scriplonen de musica medit act 2 iv, p. 214. See also Princ. 3 at CS, iv, p. 350.

For the prolix pasage 350 .

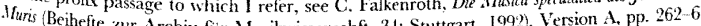
and for a translation, see T. J. McGee, The Sind of Mediecal . Husic: Omamentation and Tocal Strle For Jacque theatises (Oxford, 1998), pp. 84-5.

For Jacques on the chromatic Bragard, bk. 2, ch. 34, line 13, and App. NVutb (ii, 85 6), and see also bk. 2, ch. 38, lin 24 (ibid., p. 95) and 1)k. 5 , ch, 10 , line 9 (ibid., v, p. 33)
} 
(a)

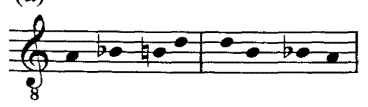

(b)

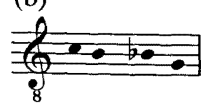

Example 1 Boethian chromatic tetrachords $(\mathrm{m}+\mathrm{M}+\mathrm{X})$ at $b-f a-\sharp-m i$ with $\mathrm{X}=\mathrm{M}+2 \mathrm{~m}$ : (a) Jacques de Liège; (b) Johannes Boen
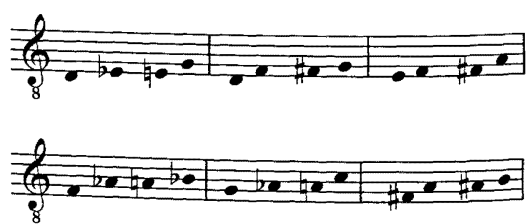

Example 2 Some Boethian chromatic tetrachords at other locations

Just a few decades later in the century, Johannes Boen is more optimistic, insisting that 'cantus cromaticus inter claves nostras leviter figuratur'. ${ }^{76}$ (His example shows a descending tetrachord: $\mathrm{C}$, B, Bb, G; see Example lb.) Of course, writing a chromatic tetrachord at any other location for the major semitone than $b-f a-\#-m i$ requires more, and more exotic, inflections, for instance, $\mathrm{D}, \mathrm{F}, \mathrm{F} \#, \mathrm{G}$ and $\mathrm{E}, \mathrm{F}, \mathrm{F} \sharp, \mathrm{A}$ (see Example 2). Boen is an enthusiast of new tonal possibilities such as these, arguing that modern musicians, like dwarves who can see farther by standing on the shoulders of giants, can now extend chromatic alterations from $b-f a-\not-m i$ to other locations in the gamut, making possible the invention of a new kind of melody that is neither diatonic, nor chromatic, nor enharmonic, but indeed 'commatic'. ${ }^{77}$ What Boen

${ }_{77}^{76}$ 'Moen, Musica, ed. Frobenius, p. 54.

quam verni maiori ducti lascivia, quasi nani super humeros gresantum plus longe respicientes quam veteres, tamquam cotidiana positione clavium fastiditi, ad subtiliores positiones dictais litteras befal mi etiam in aliis clavibus statuendo, se fastiditi, ad subtiliores positiones dic ergo novum genus modulaminis, quod nec dyatonicum netionabiliter profundarunt. ... Sic ens commaticum dicetur, posset inveniri'; Johannis nec cromaticum nec enarmonicum Corp:
A Riddle and a Song

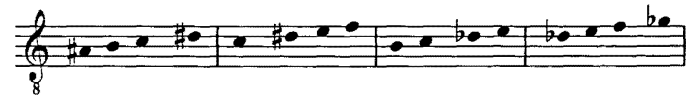

Example 3 Non-Boethian chromatic tetrachords implicit in Ut pateat $(\mathrm{m}+\mathrm{m}+\mathrm{X})$ with $\mathrm{X}=2 \mathrm{M}+\mathrm{m}$

calls the genus commaticum might be music in which commas are sung directly, since he does in fact show commas can be notated. It might also include the writing of melodic intervals with excessive commas or deficiencies in commas, which he also shows. (Singing the musical lines of the tabula figurarum of Nicolaus de Luduno would most definitely involve the genus commaticum.)

In our ballade, the notated trihemitonia are spelled as what we would now call augmented seconds ( $\mathrm{C}$ to $\mathrm{D} \#, \mathrm{D} b$ to $\mathrm{E}$ ), or major semiditones $(\mathrm{M}+\mathrm{m}+\mathrm{M})$ in the jargon of the English interval lore explored above. Assuming that they form either the top or bottom interval in some tetrachord, we can demonstrate that each implicitly defines chromatic tetrachords of non-Boethian tonal content, namely lyma, lyma, trihemitonium: $\mathrm{A} \#, \mathrm{~B}, \mathrm{C}, \mathrm{D} \sharp$ or $\mathrm{C}, \mathrm{D} \sharp, \mathrm{E}, \mathrm{F}$ incorporating the first semiditone, and B, C, D b , E or D b, E, F, G b incorporating the second (see Example 3). The striking interval succession of two consecutive minor semitones that these show is a melodic construction which Boen, for instance, enthusiastically champions, though he does not use it to construct or describe tetrachords. Given the two equal smaller semitones, these tetrachords are closer to the Aristoxenian forms described in Boethius, Book 5 than to the Boethian division of Book 4. They have the virtue of avoiding the embarrassment of direct chromaticism, which, indeed, is noticeably absent from the ballade.

These non-Boethian tetrachords prompt the following generalisations. A dyatesseron contains two tones and a minor semitone, or in other words, two major semitones and three minor semitones. Representing the minor semitone as $\mathrm{m}$, the major semitone as $\mathrm{M}$, and the trihemitonium or semiditone as $\mathrm{X}$, the Boethian chromatic tetrachord can be specified as $\mathrm{m}+\mathrm{M}+\mathrm{X}$, where $\mathrm{X}$ consists of

Scriptorum de Musica, 19; [Rome], 1972), pp. 35-6. For another vivid reference to innotations that the young like commaticum, see also Boen's Ausica, ed. Frobenius, pp. 77-8. 
(a)

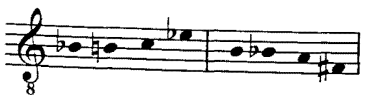

(b)

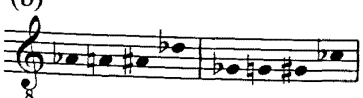

Example 4 Non-Boethian chromatic tetrachords: (a) reversing $m$ and $M$ at $b-f a-\#-m i(\mathrm{M}+\mathrm{m}+\mathrm{X}) ;$ (b) $(\mathrm{M}+\mathrm{M}+\mathrm{X})$ with $\mathrm{X}=3 \mathrm{~m}$

$\mathrm{M}+2 \mathrm{~m}$ (in some order). In Greek theory $\mathrm{X}$ is incomposite so we need not worry about its internal composition, but when projected onto the staff system, the structure of $\mathrm{X}$ will vary depending on it placement and how we imagine the whole tone to be divided Reversing the order of the two independent semitones create non-Boethian $\mathrm{M}+\mathrm{m}+\mathrm{X}$ tetrachords. These are created, for example, when the clavis $b-f a-\sharp-m i$ is at one boundary, as in the tetrachords $\mathrm{B} b, \mathrm{~B}, \mathrm{C}, \mathrm{E} b$ and $\mathrm{F} \#, \mathrm{~A}, \mathrm{~B} b, \mathrm{~B}$ (see Example ta Further, our ballade's implied tetrachords are $m+m+X$, where $X$ larger than the Boethian semiditonus by a comma, is some permuta. tion of $2 \mathrm{M}+\mathrm{m}$. And finally, we can posit a tetrachord with two consisting consecutive major semitones, $\mathrm{M}+\mathrm{M}+\mathrm{X}$, in which $\mathrm{X}$ comma and yet is smaller than the Boethian semiditonus by a This tetrat spelled as a variety of fourth (doubly diminished. $\mathrm{C} b$, for instord could be written as $\mathrm{Ab}, \mathrm{A}, \mathrm{A} \#, \mathrm{D} b$, or $\mathrm{G} b, \mathrm{G}, \mathrm{G}$. tetrachords successions $(2 \mathrm{me}$ find some of the unusual intervals and interia and Johannes $(2 \mathrm{~m}, 2 \mathrm{M}, 3 \mathrm{~m})$ that are of interest to Jacques de Liege ballade's compoen, and that take us as well into the realm of our poser.

intermediate cotic genus also has a relationship to the visual, and to the De musica of Boethius pood place to centre this discussion is again chromatic genus is a depas. In Book 1, Boethius explains that the the name chromatic departure or mutation of the diatonic, and that been said, is derived appropriate because 'this word chroma, as has
A Riddle and a Song

another colour when they are turned' ${ }^{78}$ Thus the chromatic is like all the intermediate shades of light and colour that play across a surface as the light which is directed upon it changes orientation. The steady repetition, paraphrase and summary of this explanation can be followed for centuries. To give but a single, particularly charming instance, Engelbert of Admont (d. 1331) writes in his De musica (before 1320/25): "The chromatic genus is said to be a flexible and diversely coloured mixture or medium ... whose melodies are more beautiful and delightful ... chromaticum derives from chromate, that is to say a bright object which, when appearing before a light, has a variegated appearance of diverse colours, like a peacock's tail and certain silken cloths'. ${ }^{79}$

In Book 5, cap. 16, Boethius, now paraphrasing Aristoxenus, offers a slightly different and more complicated account of the relationship of the genera, an account that in some form is also transmitted by many other Greek theorists. It also yields an analogy of inbetweenness. According to Aristoxenus, 'the division of genera is twofold, one being softer, the other sharper; the enharmonic genus represents the softer, while the diatonic represents the sharper. The chromatic occupies a place between these, participating in sharpness and softness'. ${ }^{30}$ Further, Aristides Quintilianus explicitly relates the intermediateness of the chromatic genus to the theory of visual colour: 'the genus intensified through semitones [is called] color, for just as what is between white and black is called color, so also the genus considered between both of the others is named color' ${ }^{81}$ For the Latin Middle Ages, this passage would have been familiar from its transmission by Martianus Capella and his glosses. ${ }^{82}$ Ugolino of Orvieto, in his Declaratio musicae disciplinae $(1430-5)$, provides an account of this doctrine that shows its

Boethius, Fundamentals of . Ausic, trans. Bower, p. 40.

Chromaticum vero, of Alusic, trans. Bower, p. 40 .

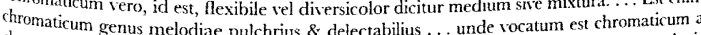
chromate, genus melodiae pulchrius \& delectabilius ... unde vocatum est chromaticum a apparens diversor est corpus lucidum secundum variatum aspectum ad oppositionem luci.'

as) Pp. $340-1$.

at Greethius, Fundamentals of Mfusic, trans. Bower, p. 175.

Mreek Musical Itritings, ed. Barker, ii, pp. 417-18; Aristides Quintilianus, On Music, trans 3. Mathiesen, pp. 83-4.

pp. 469-5 Capella, De nuptiis Philologiae et Mercurit, ed. A. Dick (Leipzig, 1925), bk. 9, p. $769-535$, at p. 510; Rémy of Auxerre, .1usica, GS, i, pp. 63-94, at p. 75 . See also n. 72 above. 


\section{Peter M. Lefferts}

familiarity down to the fifteenth century and links chromaticism directly to intermediate colours. ${ }^{83}$

The word color, curiously enough, is rarely found in theoretical passages on music outside discussions of the melodic genera and tetrachords (except for scattered rhetorical uses, on which see below). But there are instances, and, not surprisingly, they also involve chromatic alteration. For example, in his Compendium de musica, Jacques de Liège says 'sub vario colore signamus' in describing passages written with or without $\mathbf{B} b .^{84}$ Marchettus speak of 'feigned colour' when he shows the whole tone chromatically divided in a melodic descent (D, C\#, C; G, F\#, F): 'Hec enim bipartitio toni debet fieri cum colore ficticio.' ${ }^{25}$ And in what is apparently a reference to a disjunct hexachordal mutation (dismutacio) between the soft hexachord (with $\mathrm{B}$ b) and the hard hexachord (with $\mathrm{B}$ 4), an anonymous fifteenth-century author wrote 'dismutacio est mutacio a uno modo ad modum alterum vel a colore ad alium colorem' 86

\section{Color referencing rhetoric}

Beyond the visual spectrum and musical chromaticism, an additional familiar medieval meaning of color has to do with rhetoric, in the sense of colores rhetorici. This expression refers to figures of speech, that is, literary devices that embellish and beautify ordinary language. A canonic list of sixty-four in the pseudo-Ciceronian Rhetorica ad Herennium formed the basis for extensive medieval repetition and amplification. ${ }^{87}$ Modification - purposeful changeespecially for the sake of beauty and variety, provides comparability of two different states of the subject (coloured and uncoloured). It is in this sense that Johannes Boen defines colour in his Ars musice: "Est ergo color ... aliquarum figurarum in aliqua similitudine com.

${ }^{83}$ Ugolino, Declaratio, ed. Seay, iii, p. 208.

Jacques de Liège, Compendium de Musica, ed J Smits van Waesberghe (Divitiae Musicae tits ${ }_{85}$ A.IXa; Buren, 1988), pp. 88-122, at p. 105.

96. Marchettus, Lucidarium, ed. Herlinger, p. 15.; see also p. 220

${ }_{87}$ Oxford, Bodleian Library, MS Bodley 842 , fol. $77^{\circ}$.

For a standard treatment, see J. J. Murphy, Rhet Theong from Saint Augustine to the Rencissance (Bertoric in the Middle Ages: A Histon of Ritw the Appendix Book IV".
A Riddle and a Song

parabilitas.' ${ }^{8}$ Most generally, colour may mean qualitas, and the verb may mean to give a special meaning or aspect to, or to modify or put a particular spin on. ${ }^{89}$ But by far the most frequent synonym for colour is pulchritudo, and for the verb colorare we find decorare, variare, purpurare. ${ }^{90}$ Without expressly using the Latin pulcher in any form (perhaps deliberately avoiding it?), the beauty that is the purpose of the colores rhetorici can be imputed to our ballade text by the connotations of decens and distinccio in the expressions 'cordis decentibus' (line 5) and 'ut sit distinccio' (line 13).

Under this governing rhetorical concept one can distinguish two principal usages in medieval music theory that emerge in the later thirteenth and early fourteenth centuries. First, colour may refer to a change made to an individual note, which may be modified by the addition of a sharp or flat chromatic inflection (as seen above) for the sake of beauty, or be directly changed in visual colour from black to red for mensural purposes (a use to which we will return to below). Second, colour may refer to musical elaboration by the generation, repetition and variation of musical figures (sometimes structurally, other times as elaborations or embellishments) in one or more voices.

Concerning the second of these usages, a number of distinguishable applications stand out. First is change to an individual note encompassing rhythmic elaboration or the substitution of a more elaborate melodic figure. Colour may instead refer to larger-scale melodic repetitions that occur in one and the same voice (in a monophonic or polyphonic context), or in different voices of a polyphonic work (as in polyphonic rondellus, imitation and voice exchange). Finally, colour as repetition may apply to the description

${ }^{x_{3}}$ Boen, Musica, ed. Frobenius, p. 29.

See Jacques de Liège, Speculum musice, ed. Bragard, bk. 7, rii, pp. 21 and 23. In Speculum musice, b. 6 (vi, p. 247) Jacques observes that when one defines a given final in plainsong, then the other notes are seen and 'colored' by their relationship to that final: 'per finalem colorantur et decolorantur cetere voces'. The same point was made in an anonymous commentary on, Guido's . 1icrologus, with 'colorantur id est decorantur' for 'colorantur et decolorantur'
Expositiones in. Vicrologum Guidonis Aretini ed. J Smits van Waesberghe (Amsterdam, 1957), p. 133).

2 color as pulchritudo, sce, e.g., Johannes de Garlandia, De mensurabili musica, ed. E. Reimes, Liege aliesbaden, 1972), i, pp. 74, 95. For colorare as decorare, see previous note; Jacques de Liege also equates colorari with decorari in Spectum musice, ed. Bragard, bk. 6, vi, p. 98 . For iantare and purpurare, see De musica mensurata: The Anonymous of St. Emmeram, ed. J. Yudkin (Bloomington, 1nd, 1990), p. 170, line 37 (propter colores musicae decentius purpurandos ac elian variandos') and p. 206, line 34 ("propter colorem musice purpurandae et variandae"). 
Peter M. Lefferts
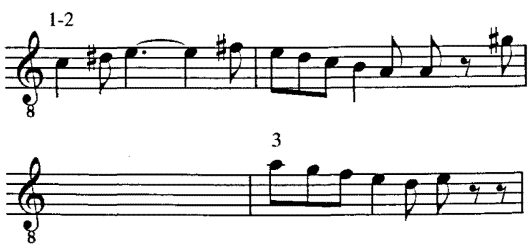

$4-5$

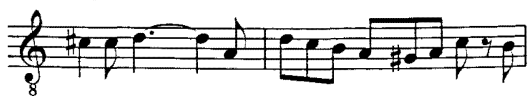

Example 5 Cantus line: extension by varied repetition

of isorhythmic tenors of fourteenth-century ars nova motets, differentiating between melodic and rhythmic figures as color and talea.

Returning to the musical fabric of the ballade, we thus can understand it not only as coloured by chromatic inflection, but also as coloured by repetition and varied repetition. Most broadly, this rhetorical meaning is referenced by the choice of song type-ballade - with its conventional threefold (here sixfold) performance and the double versicle (I.1, I.2) constituting the prima pars. One of the other fixed forms, or even an isorhythmic motet, would have fulfilled this meaning equally well. In a carefully constructed ars nova polyphonic song, however, a web of interrelated rhythmic-melodic motifi dominates the musical surface, contributing to a sense of both continuity and coherence. Thus the ballade also can be understood as an apt vehicle for more local repetitions, a potentiality thorought: exploited by the composer of this one.

Polyphonic imitation is a distinguishing feature of bar 1, whose opening cantus motif and its echo down an octave layer colour (rhetorical) upon colour (chromatic). Perhaps one is also intended to hear the returning-note figures of bar 4 in the tenor and bar 5 in the cantus, in the same metrical positions and just a step apart in the same register, as imitation. More subtly, bar 3 in the cantlis transposes and varies the second bar of the opening phrase, after which bars 1-2 are transposed and varied as bars 4-5 (Example $j$ ? The recurrence here of the cadential figure (Example 6a), with is trochaic lilt and repetitive anticipation, is memorable, but evell
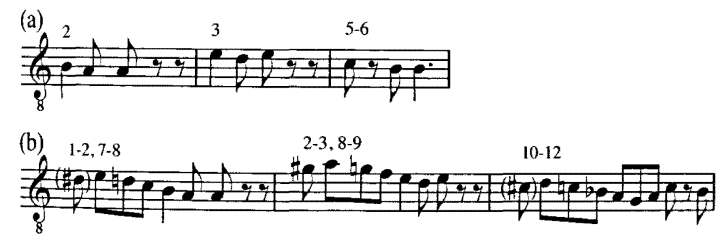

Example 6 Cantus line: (a) cadential figure; (b) TTmT descending pentachord and varied conclusions in section $\mathrm{I}$

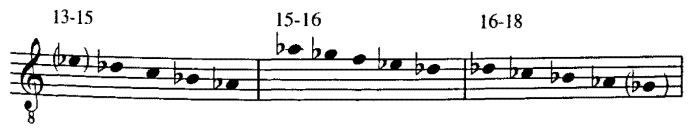

Example 7 TmTT descending pentachord in section II

more significant for the passage is the unfolding of the motif of a rising half-step followed by a descending TTmT fifth (where $\mathrm{T}$ is tone, i.e., $\mathrm{m}+\mathrm{M}$ ), which is presented three times, moving flatwards by cycle of fifths from $e$ to $a$ to $d$ (Example 6b). In my reading of 1.1 and I.2, the third of these offers an exact transposition of this figure only in its second statement. The conclusion of the figure is different each time, progressively cadencing on the bottom pitch, then a step above, then two steps above.

The ballade's secunda pars begins with section II. Here we find a varied restatement of I.1/I.2 that has been rhythmically compressed on account of the change of mensuration and continues the flatward swing in tonal content, presenting most of the tonal content of section I down a half step (Example 7). The descending fifth figure is projected in three fresh variations (on $\mathrm{E} b, \mathrm{~A} b, \mathrm{D} b$ ), whose tonal content has been recoloured from TTmT to TmTT. The first variation of bars 13-15 (Eb, Db, C, B b , Ab) lacks its opening Eb, because $\mathrm{D} b$ is desired as the initial sonority for other reasons (tenor motifs and falling-third accidentals, I would presume). The third variation of bars 16-18 ( D b , C b , B b , Ab, Gb) is also truncated and raises its anchoring $\mathrm{G} b$ so as exactly to repeat the cadential lower half-step returning-note motif. In the tenor (Example 8), the motif of section I, bars 2-3 $(C D E D)$, which is taken up a step in bars 5-6 


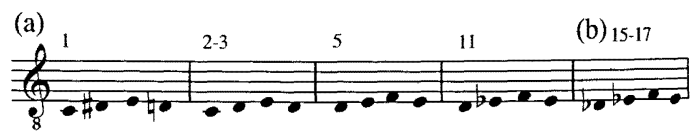

Example 8 Varied tenor figure: (a) section I; (b) section II

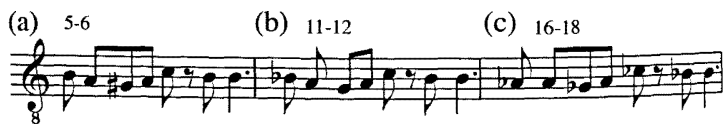

Example 9 Cantus line: 'coloured' cadential figures: (a) section I.1; (b) section 1.2; (c) section II

$(D E F E)$ and varied in bars $11-12(D E b F E b)$, is varied again in section II $(D b, E b, F, E b)^{91}$

The ability variously to modify a motif by the use of chromatic inflections, shifting its tonal content and location in pitch space while it remains tied to the same claves in the staff, is most dramatically epitomised by the cadential figures of section I.1 (bars $5-6$ ), section I.2 (bars 11-12) and section II (bars 17-18), which include the now notorious acute $c b$ (Example 9). All these figures are intermediary between the version in which every note is sharpened and the version in which every note is flattened. Each reflects its own individual colour, participating to one or another degree in the extremes of flatness and sharpness. The parallelism to the Aristosenian dogma of Boethius, De musica, Book 5, could not be plainer.

The remainder of the secunda pars, with its mensural shift to duply divided semibreves, lacks strong motivic ties to sections I.1, I.2 and II. Nonetheless, tonal links are carefully forged. The first two bars of section III revolve around the same acute $b$ b that ended section II. but with natural $d, a$ and $c$ (Example 10a). The tenor operates throughout section III within the $F$ to $C$ fourth whose boundar tones are a half-step lower than the mT $G b$ to $D b$ of section II. returning to the grave $C$ that is the lowest pitch of section I. The $F$ to $C$ fourth is first filled TmT $(F E b D C)$ and then TTm $(F E b D$ b ${ }^{91}$ The tenor of II moves entirely within a descending mTT fourth $(G b$ to $D b)$, which is mirrored
up a fifth $(d b$ to $a b)$ by the cantus in bars $13-15$
A Riddle and a Song
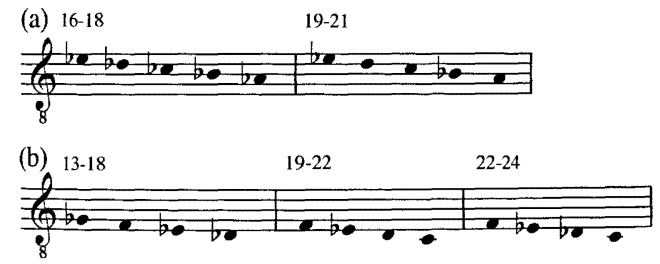

Example 10 Colouring across sectional boundaries: (a) cantus line, end of section II and beginning of section III; (b) tenor line, section II and section III

(a) 25

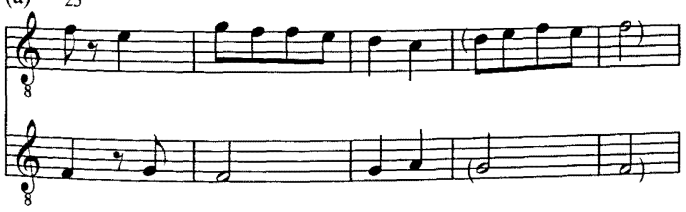

(b) 29

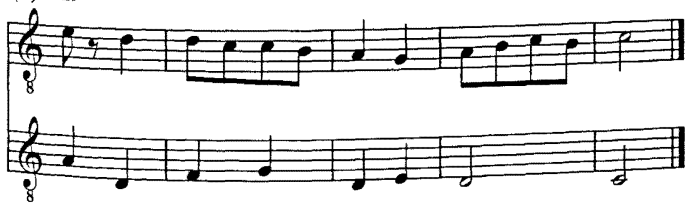

Example 11 Transposition and variation in section IV: (a) first half of section IV; (b) second half of section IV

C). The shift in location of the semitone - mTT, TmT, TTm - is surely not coincidental (Example 10b).

By the end of section III, the initial $b b-E b$ sonority has risen a whole tone to $c-F$. Sections III and IV are linked by $F$ sonorities and parallel melodic figures: cantus $g$ fe $d \mathrm{~b} c$ in bars $23-4$ is followed by $g f e d_{c}$ in bars 25-7 (Example 11 a). The gradual sharpening evident in sections III and IV is seen in microcosm within section IV alone, whose second half is seen in microcosm withed transposition and sharpward rotation of the first half (bars 25-8), moving from an $F$ 
Peter M. Lefferts

environment to a $C$ environment in the tenor, with corresponding motivic TmTT fifths in the cantus running first from $g$ to $c$ and then from $d$ to $G$ (Example 11b). Full tonal closure on the cantus-tenor octave $c-C$, matching the initial sonority of the ballade, is achieved only at the final cadence.

\section{THE TEXT: STANZAS 4 TO 6 AND MENSURAL BEHAVIOUR}

Returning once more to the poem, we may now examine the relationship of its fourth to sixth stanzas to the song's mensural behaviour. This requires us first to parse the ballade's phrases into regular mensural units, which is straightforward and yields the following results. Segments I. 1 and I.2 last six breves each in tempus perfectum prolatio maior for a total length in the prima pars of $2 \times 54=108$ minims. This total is highly significant numerologically, as it is the product of the second power of 2 and the third power of $3\left(2^{2} \times 3^{3}\right)$. The three segments of the secunda pars are articulated by mensuration changes in such a way that the length of section II is six breves in tempus imperfectum prolatio maior (36 minims), section III contains six breves in tempus perfectum prolatio minor ( 36 minims), and section IV contains nine breves in tempus imperfectum prolatio minor ( 36 minims), for the same total length in the secunda pars as in the prima pars, that is, $3 \times 36=108$ minims. The mensural features just described are discussed, albeit very obliquely, in the second half of the text.

Stanza 4 refers to the ballade's progression through four different means of mensural organisation under minim equivalence without the use of mensuration signs to signal each in turn, and indeed, the Philippe tetras formas (line 25) surely refers to 'les iiij. prolacions' of profound novelty. Here we must remember that the most 92.

the sense of the Greek tetras in this expression is extremely unusual There is no problem with of compounds (e.g., tetrachord) music theory the word does not othenvise appear outside encountered definition of the term ding (monas, dyas, trias, tetras) and in the frequently Auxerre, Mflusica, GS, i, that 'dicitur diatessaron a dia the author intends a pun on quod est de et tetra quod est quatuor'. The possibility exits that prompt a variant trans on taeter, taetra (offensive, horrible) a ner. The posibity that would stanza is that the formation reading compellenter as 'compelled, forced', aso that the sense of the reverse the whele pois are being forced on the compelled, forced', so that the sense of the reverse the whole point of the stang forced on the notes. I reject this possibility, as it seems 10
A Riddle and a Song

Johannes de Muris and Philippe de Vitry over the first quarter of the fourteenth century had been a reconceptualisation of the metrical hierarchy, moving from the position that rhythmical values were multiples or fractions of a central value, the breve, to a new posture in which all values were multiples of a fixed smallest unit, the minim. If all minims are equivalent, then on the most local level all rhythmic activity is just a flow of successive minims and groups of minims onto which larger-scale mensural organisation can be imposed by features of rhythm, melody, counterpoint and harmony. The ballade clearly demonstrates this capacity. It remains to be asked whether the demonstration is introductory in original purpose, advertising a new approach to a conservative English audience, or whether it may be defensive in intent, supporting the status quo against further innovative pressures. ${ }^{93} \mathrm{I}$ will defer an answer to this question for a moment.

Stanzas 5 and 6 reaffirm that their author follows a classically Parisian ars nova posture through their insistence on the minim as smallest value, the counting unit of the mensural system. Just as in an arithmetic of whole numbers there is no place for fractional values, there is in stanza 5 the scornful refusal to countenance semiminims. Rather, one builds rhythmically and mensurally in multiples of a unit value (the prima nota, line 37 ), in a process that is both musical and mathematical. The language of calculation (ratas $d a n d o$, line 39) is evoked in these stanzas just as it had been in the first three, reminding us that the discrete values of musica mensurata provide a field of numbers within which to play, expanding the way in which music can express number. In particular, on the evidence of the ballade, our composer believes that the notational system's capacity for representing proportions should be expressed in section

${ }^{93}$ Looking at the manuscript context, the ballade keeps company with fairly mainstream material. In the St. Paul fascicle the Turris quem totum comprehendit renum originem creaturanum immediately preceding the tabula monucordi presents a standard gradus system of $\$ furis with five figures, four levels and values from 1 to 81 minims. Other northern French ars nora theory in the larger manuscript includes a version of the Ars noia atributed to Philippe de Vitry, the Sotitia artis musicae, Co includes a version of the Ars noita attributed to Philippe de Muris-derived Regulampendium musicae practicae and Libellus cantus mensurabilus of 842 there are notationaled Regulae de mensurabili musica of Imbertus de Francia. In Bodley values), treatises by Franco and Willelmus (Willelmus is mildly progressive in respect to note on there is a brief tractatur the Noticia artis musicae of Muris. Ironically, just three pages furcher describing the classic four ars noza mensuration signs. 


\section{Peter M. Lefferts}

lengths computed in minim counts, rather than in any other possibilities. ${ }^{94}$

The lack of signs to announce the changes in mensural organisation seems to be the point of the expression 'temporibus ficticiis absentibus' (lines 25-6). The most difficult word here is ficticiis. One way to take it is as 'imagined' (visualised, formed mentally), in the sense that because signs are not used, they must be imposed by the mind ('absent but imagined'). That is reasonable. Also tempting. however, is a more negative connotation, namely that mensuration signs are somehow bogus (fictitious, feigned) and as a consequence they can successfully be done without. The latter is a plausible position for an adherent of minim equivalence to take, and the 'notarum equivocarum' of lines 22-3 are undoubtedly minims. Under minim equivalence, one should not need mensuration signs once the absolute novelty of mensurations has worn off, as long as care is taken to recognise duple and triple organisation (because of the workings of alteration and imperfection in triple metre).

Arguing along lines suggested by the behaviour of accidentals in this ballade (or in Boen's Musica), signs ought properly to possess potency; they ought to be agents of change, modifying their environment. If mensuration signs are passive markers, they merely mark a spot, pointing to phenomena that would exist even if signs for them did not. Thus they are inessential, feigning a power they do not possess, and need not be used.

I suspect it is far from coincidental that both stanzas $1-3$ and 46 involve 'fictising'. The expression musica ficta, however much implicit in the ballade's tonal behaviour and first three stanzas, is only slyly referenced now. It would not have suited the first three stanzas behaviours and ficta is hexachordal terminology, and hexachordal behaviour. and concepts are not pertinent to this ballade's tonal surely self-consciouscation of fingere/ficta at this point in the text is historical understan, an ironic displacement. And it reinforces our that the termintanding that is only in the fourteenth century that the terminology musica ficta emerges for the first time as an

\footnotetext{
${ }^{94}$ Other possibilities for the expression of numerical proportion not explored in this ballade coult temary semibreves, or the equalace of three on the minim level, the equality of binary and
}

A Riddle and a Song

alternative to musica falsa, though rarely employed and, as here, only in English and northern French sources. ${ }^{95}$

Other technical jargon in stanzas 4 to 6 deserves brief mention. I have read tempus as 'time-measures' (in the sense of mensuration signs) in the crucial expression 'temporibus ficticiis absentibus', but I admit that this reads back into the text what I see in the music rather than attempting to take the Latin at face value. In the context of ars nova theory, tempus most often refers to the mensural relationship of breve to semibreve. Similarly, prolatio (line 41) most often refers to the binary or ternary mensural relationship of semibreve to minim. However, in stanza $6 \mathrm{I}$ have interpreted prolatio in its most familiar non-technical sense as 'utterance', thus understanding the passage to mean that when all the minims and multiples of minims have been laid out properly, making good music (eliganter) and correctly fulfilling all mensural obligations, then a coherent, performable piece arises. Alternatively, this could be an assertion that in the end, there really is only one prolation; the work can be realised by counting the steady succession of minims without concern for whether they group into twos or threes. Another technical term from ars nova theory, gradus (line 40) may refer to the four mensurations or may evoke the gradus system of Muris, a mensural hierarchy based on multiples of the minim.

Returning to the matter of the meaning of the refrain line, what might our mensural sieve be? Perhaps the notational minims are as the uniform grains of wheat held in a sieve. Or we could imagine the four mensurations as four different sets of chain lines pressed into the neutral medium of successive minim durations. Thinking diagramatically along the lines of the cribrum monochordi, one could produce a grid by the juxtaposition of four different groupings of $\left(2^{2}\right) \times\left(3^{2}\right)=36$ minims, aligning $9 \times 4,6 \times(3 \times 2), 6 \times(2 \times 3)$, and $4 \times 9$. Alternatively, it may simply be that we have a none too burdensome demonstration that there can be more to the notation than immediately meets the eye.

${ }^{45}$ For the fourteenth-century instances of the use of the term musica ficta, see Anon., Circa modum discantandi (London, British Lintances of the use of ( $^{\mathrm{v}}-11$, at 10); A. de la Fage, Essuis de diptherographie musicale (Paris, 1 rary, Add. Tallicelliana, B.83); Philippi de Iitric p. Liber musicalium, CS, iii, pp. 35-46, at p. 45; Anon., Ars contrapunctus secundum Philippi de litrato Liber musicalium, CS, il, pp. 35 and The Berkeley. Hanusrript, ed. Ellsworth, p. 51 . 


\section{Peter M. Lefferts}

Absent from stanzas 4 to 6 is any mention of colour. Yet the ballade's behaviour requires consideration of one additional role for colour, and this is colour in respect to proportion and mensuration A well-known innovation of early French ars nova notation is the use of red coloration to indicate a change of note values and mensura organisation, usually from ternary (perfect) to binary (imperfect) on one or more levels of the mensural hierarchy. In the late fourteenth and early fifteenth centuries, the use of solid or void note heads in black, red and blue permitted coloration to express very complicated proportional and mensural relationships overriding minim equivalence. Our ballade, of course, uses exclusively black notation described in its mensural behaviour might have been conceived and described in terms of colour. Justification for this assertion comes (early fiftem an anonymous English treatise De origine et effectu musicat which feenth century) in a brief paragraph, 'De coloribus musice', perfectates: 'Tres sunt colores musice pro arte practica, scilicet hues are inperfecta, semiperfecta. ${ }^{96}$ Without saying if actual visual an intermended, this compactly defines a system of contraries with I take it thate as it asserts a relationship of colour to mensuration. binary, which perfecta refers to ternary organisation and inperfecta to theory. which is standard terminology in late medieval mensural perfecta of nine minime, in respect to breves there could be a bretis inperfecta of four minim, a brevis semiperfecta of six minims and a brem durations of minims. This is exactly the sequence of proportional Might they ime breve in our ballade. Shall we call them colours? Amplification in invoke black, red and white?

colours is found a doctrine of proportions and mensurations as concerning the six some obscure later English music theor? material is $c .1430$ in heraldic colours. The first glimpse of this paragraph about the Lansdowne 763 , fols. $88^{\mathrm{v}}-89$, in a cryptic colours ('Distinccio the distinction between musical and armorial which we learn that ther colores musicales et armorum heroum'), in are sung in songs when are six natural colours and this is how they vocantur in canticis present ('Sex sunt colores naturales ... . et sic (black, white, red, bluando stant'). The given colour sequence tis eory', Alusica Disciplina, 37 (1983), pp. 109-19, at p. 115 .

\section{A Riddle and a Song}

from best to worst in heraldry and from worst to best in music. A different colour sequence is also identified in the same text (black, green, blue, red, white, yellow) and similarly described. But no further explanation of these alternative colour sequences, and no direct musical application of the information, is in fact offered. Nonetheless, the Lansdowne material surely adumbrates several paragraphs in the much later musical commonplace book of John Tucke (London, British Library, Add. MS 10336, first quarter of the sixteenth century).

In Tucke's book, two doctrines of colour and proportion are found. First, we learn that 'The colours requisite to musical proportions are these: black, green, blue, red, yellow.' This series is most similar to the second colour sequence in Lansdowne. An analysis of the specific proportions that are prescribed for each colour pair (e.g., green to black is 9:8, and so on) demonstrates that Tucke's sequence is virtually a musical scale of colours. ${ }^{97}$ Several paragraphs later he announces a different sequence for the heraldic colours (white, black, yellow, blue, red, green) and implies that these are in a gradient from more noble to less noble in a manner reminiscent of the Lansdowne doctrines. He goes on to explain that the quality and quantity of colours, when applied to note shapes, are said to dictate their relative values and proportional relationships. ${ }^{98}$ Without resolving the conflicts in colour order or addressing the practicality of what he seems to be describing, we can safely say that Tucke's broader context makes the clear association of colour to proportion, and of proportions and colours to mensuration.

The notational sophistication implied by Lansdowne and Tucke is found in sources of English polyphony from the Old Hall Manuscript (London, British Library, Add. MS 57950, c. 1420) down to the early sixteenth century. Their use of semiminims, and of proportional relationships abandoning minim equivalence, would

${ }^{37}$ The sequence and the stated proportions between colour pairs predicate a colour scale equivalent to the following diatonic musical scale: $\mathrm{C}$ (black), D (green), F (blue), G (red), B b (yellow) and $\mathrm{C}$ an octave higher (if black void mav be understood as white). The analogy to the scale is my own, from information in Woodley, Tucke, pp. 68-71; the quotation is from p. 69. Diaghonicos is a remarkable device, and it occurs when a piece of music is composed through the use of heraldic colours; for this, it should be known that there are six heraldic colours, the names of which are these: for this, it should be known hat dhe second sable; the thir or; the fourth are these: the first and principal colour is argent; the second sable, the thind the nobility of the coloure; the fifth gules; the sixth vert. And it is necessary to bear in mind less noble one.' Woodleyrs, because a more 


\section{Peter M. Lefferts}

have been abhorrent to the composer of our ballade. (He is as conservative in mensuration as he is progressive in tonal behaviour.? And yet, in an early formulation, an evocation of the relation of colour to proportion and mensuration that would later take such a complex turn might credibly be understood as within the intention of our author. If so, the term color is explicit in the first three stanzas and implict in the second three just as, reversing the order, ficta is implicit in the first three and explicit in the second three.

Let us return to the deferred question of fourteenth-century chronology and mensural practice. In Ut pateat evidenter, the note of contention, of demonstration of the logic and capacity of a system, and of a delight in hiding and revealing meaning, all speak to the currency in the mind of its author of the issues addressed above. This posture suggests we have arrived at a moment when mensuration signs are beginning to be found necessary (which makes a comfortable fit with a date after mid-century for our ballade because of experimentation with large-scale sectional changes of mensuration, proportional changes in one voice against all others, or proportional relationships other than minim equivalency between sections. (The latter two are possibilities inherent in fourteenth-century English and Italian notational systems that developed within French ars nova practices only over the last third of the century.) And, of course, it would appear to be a moment when semiminims are emerging into ars nova notational practice. If there is a local English context for these concerns, it might well be from the era of Johannes Hanboys, in whose Summa $(c .1370)$ there is still discussion of insular 'longa mensura', with smallest values that a Francophile would identify as proportional minims or semiminims, but whose larger preoccupation is in expanding the gradus system of Muris systematically to encompass smaller values than the Parisian minim, perhaps in the face of compositional activity that was already exploring this possibility within a nominally Francophile
context. 99

See P. M. Lefferts, Robertus de Handlo, Regule and Johas Hob pp. 38 64. The compositional activity I have in mind Hanboys, Summa (Lincoln, Nebr.,
large-scale Enow large-scale English cantilenas with semiminim in mind consists of the later fourteenth-centuin one finds in Cambridge, Gonville and Caius and sectional changes of mensuration such was no novelty , and New York, Pierpont Morgan was no novelty in England in the later fourtergan Library, MS 978. French ars nota nota

\section{A Riddle and a Song}

\section{FINAL THOUGHTS}

The greatest value for us in an exercise like the ballade $U t$ pateat evidenter lies in its evident origins as a self-conscious demonstration piece. In such a work, conceived in a spirit of play and perhaps even of competition, the author challenges his audience to discover his intentions. Even without the lyric's clues, much can be drawn from the notation and the resulting musical fabric alone. Some systems of thought - in this case within the realms of tonal and mensural behaviour - are being demonstrated; some potentialities inherent in some systems are being explored. ${ }^{100}$ I would readily grant the argument that what we see here may not be customary and traditional musical behaviour. But it allows us an unusually explicit point of entry into medieval thought about music.

The poem that is our ballade's lyric dramatically expands the analytical field for us, alerting us to additional dimensions of meaning and allusion. Some of what it says is now obvious, although some is still obscure, and the full richness and intention of its meaning may never be fully recoverable. Its author might rejoice in that, for he is quite evidently having fun, playing with the meanings of words and signs - riffing verbally and musically with material that he would have assumed familiarity with on the part of his elite audience. As is more directly apparent in the roughly contemporaneous Fumeux fume, written for a clique of fumeurs (a kind of informal and only half-serious French intellectual academy whose charter was written by Deschamps in 1368), we surely have here a piece for an in-crowd of cognoscenti. 101 Further, this ballade's intertextuality and musical self-referentiality tie it to a wider international repertoire of polyphonic songs and motets whose texts refer explicitly or

at least the later 1320s or early 1330s, as attested by the music source Berkeley Castle, Selec Roll 55.

There is a fundamental difference between musica ficta essays that are systematic and those that are not, a point He is hostile that to my mind is not adequately articulated by Brothers in Chromali Baically de is hostile to analytical approaches that insist on a hegemony of uniform, theoreticaly derived rules (p. 10), welcoming instead the recognition of flexibility, discursiseness, idiosyncrasy, digression, deviation, inconsistency. This position yields many valuable individual insights, but it ultimately blinds him to the potential value of those few remarkable compositions whose very purpose is to reveal a system. Exploration of both kinds of tonal hehaviour are necese very purpose is to reveal a system. Exploration of both icture of theor and practice.

Leffers, 'Subtilitas in the Tonal Language of Fumeux fume', p. 180 and n. 10. 


\section{Peter M. Lefferts}

obliquely to musicians and musical behaviours, from the wellknown complex of musicians motets with its own cross-channel connections, to Fumeux fume and other chansons. ${ }^{102}$

Details of tonal and mensural practice allow us to contextualise the song within a rigorous discourse that we can identify with an intersecting and evolving network of materials and individuals whose point of origin is England and northern France, although at least two important surviving sources of most immediate interest were copied in Sicily or southern Italy, in the realm of Angevin Naples. ${ }^{103}$ It is at a time when notational signs are being reconceptualised as potent agents, not just as markers, and when proportional innovations are threatening minim equivalence in French ars nova practice. As for a date, a reasonable estimate for our song is the third quarter of the fourteenth century, just a few strides beyond positions staked out in the Musica (1357) of Johannes Boen. Its author is surely a contemporary of Boen or of Nicolaus de Luduno, but likely to be English. If our knowledge of medieval tonal theory can be likened to a jigsaw puzzle, then Ut pateat causes us to realise that the large number of pieces assembled by Karol Berger form a part of the image belonging not in the dead centre of the picture, but lower and to the right, towards Italy as it were, with an upper left part of the puzzle (Anglo-French theory) still lacking many pieces but emerging as a distinct area in its own right, however much it may interlock with other parts of the picture. ${ }^{104}$

I will close with the observation that Ut pateat evidenter, in as full a context as I can generate for it, teaches us that in the later fourteenth century, western European composers and theorists had

${ }^{102}$ For texts of polyphonic songs pertinent to the issue of fixed versus proportional minims and di semiminim, see A. Stone, 'Che cosa c'è di più sottile riguardo l'ars subtilior?', Rivista lutiars di Musicologia, 31 (1996), pp. 3-31, and U. Günther, 'Das Ende der Ars Nora', $D$ ' (1) 3 The importation (1963), pp. 105-20.

The importation of northern (French and English) theory into Italy is documented not ont by the Rome/St. Paul and Catania and English) theory into Italy is documented not ont G. de Anglia in 1391 in Payania manuscripts, but also by the activities of the copyist frat library, IIS 54.1, entering the where he worked on the manuscript now Chicago, Newbert The Chicago manuscring the treatise of Petrus de Sancto Dionysio and perhaps other iterts illustration othenuscript contains on fol. $9^{\mathrm{x}}$ a seven-figure Torkesey triangle, a version of this more on the Englise known only from Bodley $8+2$ (see Lefferts, Handlo and Hanbo's, p. 56). Fo Treatise of the The influence on Trecento music theory, see P. M. Lefferts, 'An Anon!mos'

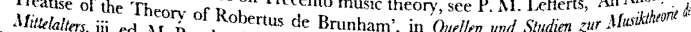

in $\begin{aligned} & \text { Afittelalters, iii, ed. M. Bernhard (Munich, 2001), pp. 217-51, an pp. 238-43. } \\ & \text { Karol Berger had seen }\end{aligned}$ Karol Berger had seen Boen and Nicolaus de Luduno as isolated and exceptional (114usiaf fitit
pp. 30-3).

\section{A Riddle and a Song}

no one single way of thinking about tonal behaviour. Thus we today must reject 'one size fits all' explanations that exclusively champion modality, hexachords, pentachords, tetrachords, keyboard thinking or any other single 'system' as the key to all behaviours, and thus to all analyses, of later medieval music. Rather, we must acknowledge the exploration by musicians of a variety of possible ways to imagine, describe and traverse musical space, with varying degrees of rigour or idiosyncrasy. Our ballade's music and text exemplify certain tonal (and mensural) concepts, demonstrating certain possibilities with a degree of enthusiasm and contention that clearly points to the existence of alternative schools of thought. It sets a challenge to its contemporaries with a riddle and a song.

University of Nebraska 


\section{Peter M. Lefferts}

\section{APPENDIX 1}

Text and Translation of Ut pateat evidenter

[1.] $\mathrm{Vt}$ pateat euidenter monocordi quot et quibus pleri licet nescienter diuersis a communibus cordis canant decentibus ut calculi fert racio Cribrorum demonstracio

[2.] Omnes pandi differenter veteres has marginibus albis pure condecenter pure nigris has tractibus set mediis coloribus

nouas ut sit distinccio Cribrorum demonstracio

[3.] Inuentasque consequente puta non cum ueteribus nec eciam tam recenter ac si cum nouioribus pandi fuscis tingentibus sese colore uario Cribrorum demonstracio

[4.] Et notarum contingenter equiuocarum sitibus cautis dari compellenter tetras formas temporibus ficticiis absentibus loco quamque set proprio Cribrorum demonstracio

[5.] Vtque fiat vehementer confusio fauentibus semiminimis patente nequaquam possibilibus ac prorsus inutilibus cuius tanquam probacio Cribrorum demonstracio

[6.] Transferendo diligenter primam notam ex omnibu ad quam placet eliganter ratas dando sequentibus quod diuersis ex gradibus una surgat prolacio Cribrorum demonstracio
So that it may be plainly visible on how many and which suitable strings of the monochord different from the ordinary ones

5 most perform, albeit without understanding. as the reckoning of calculation bears out - the demonstration of sieves

Think that all are set out differently: some old (pitches), as is proper,

10 in the purely white spaces and others on purely black lines, but the new ones on intermediate colours, so that there might be a distinction - the demonstration of sieves

15 And that those (pitches) invented subsequents: not together with the old ones, nor yet so recently as if together with the newer ones, are set out with tinted things

20 dipping themselves in varied colour - the demonstration of sieves

And that the four forms of equal-valued notes are presented, brought together 25 one after the other,

the unneeded time-measures being absent, with each form in its own place - the demonstration of sieves

And so that confusion

30 may thoroughly befall the supporters of semiminims, which are clearly in no way possible and completely useless,

of which fact the proof so to speak

35 is the demonstration of sieves,

By diligently transferring the first note of all

to that which one pleases in a fitting way and giving fixed shares to those after 40 so that from different degrees one utterance [i.e., this song] may arise - the demonstration of sieves

\section{A Riddle and a Song}

$\mathrm{Ob}=$ Oxford, Bodleian Library, Bodley 842; $\mathrm{StP}=$ Sankt Paul im Lavanthal in Kärnten, Stiftsbibliothek (Archiv des Benedictinerstiftes), MS 135.

7 Ob: Tribulor; StP: Cribriorum for Cribrorum

$9 \mathrm{Ob}$ : ne te res for veteres

$19 \mathrm{Ob}$ : sustis/tris, StP: fustis/tris for fuscis

$19 \mathrm{Ob}$ and StP: tangentibus for tingentibus

22 StP: Ex for Et

$23 \mathrm{StP}$ : sitibus illeg.

24 Ob: cantis compellenter; StP: dare for dar

27 StP: ad quancunque for loco quamque

38 Ob: elegenter StP: eligenter for eliganter

to StP: quam for quod 
Peter M. Lefferts

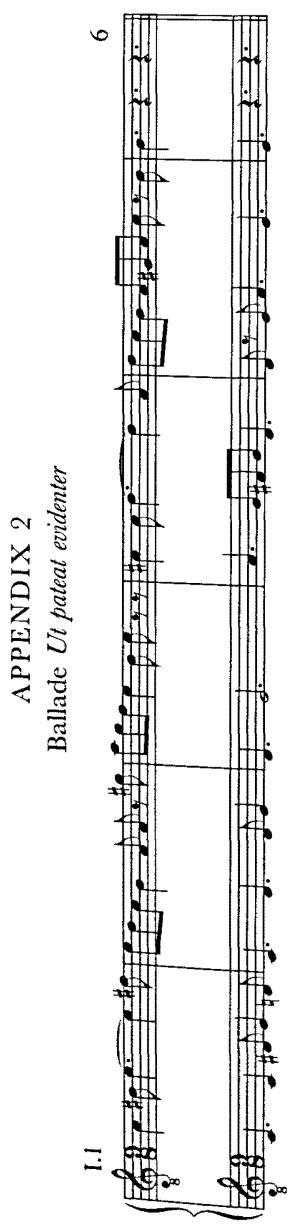

I

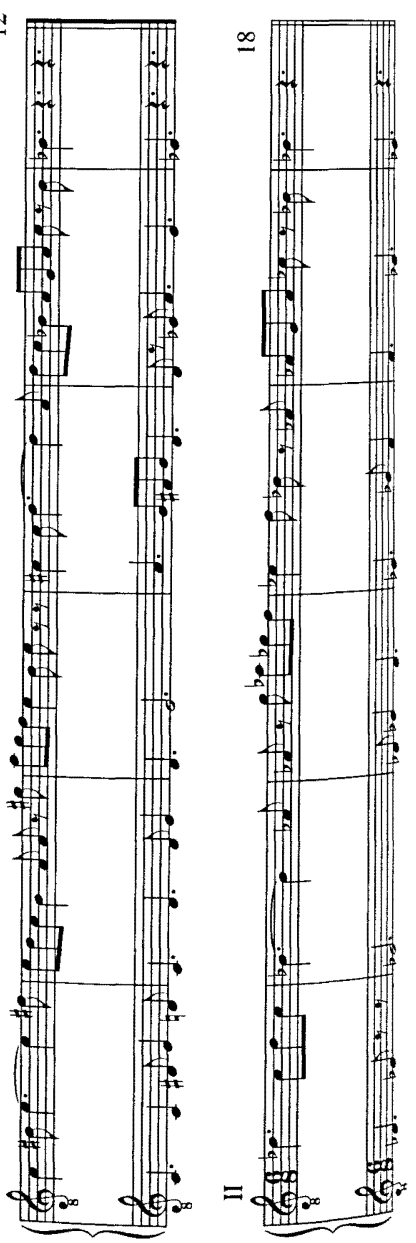

178
A Riddle and a Song

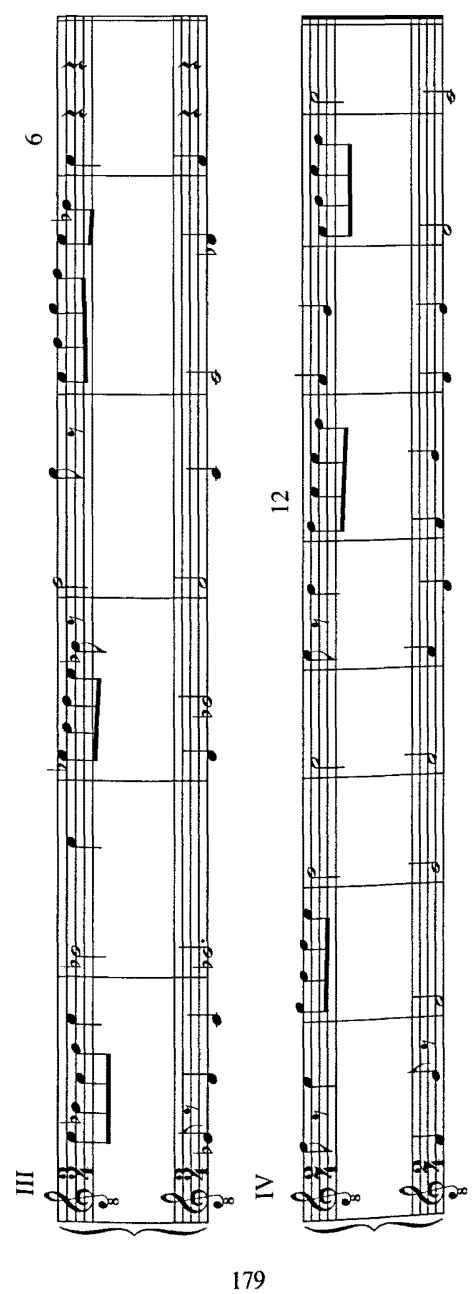

